\title{
Mitigation Matters
}

John Blume and Russell Stetler

\section{Introduction}

Mitigation matters. It works. It literally saves lives every day, often in cases in which a death sentence seems a foregone conclusion. But mitigation matters-it works_-only if the capital defense team is committed both to conducting a comprehensive investigation of the client's life and to developing and integrating the results of the investigation into a compelling, credible narrative for life. This commitment to uncovering and telling the client's true story must be complete and unwavering. When it is, life sentences follow. When it is not, undeserved death sentences are imposed.

Mitigation made this precise difference in Juan Quintero's case. Quintero was charged with the murder of Rodney Johnson, a decorated veteran Houston police officer. ${ }^{1}$ After a traffic stop, Johnson arrested Quintero when he could not produce a driver's license or any other form of identification. Johnson frisked Quintero but somehow missed a 9-mm pistol Quintero had hidden in the waistband of his pants. Although his hands were cuffed behind his back, Quintero managed to get the gun out of his pants, turn, and shoot Johnson seven times. To make matters worse, Quintero was in the country illegally; he had been deported back to Mexico years earlier after pleading guilty to sexually assaulting a twelve-year-old girl.

Quintero's team did not despair that their client was charged with killing a cop in death-friendly Harris County, the buckle of the Texas death belt. Instead, they rolled up their sleeves and went to work. After spending numerous hours with Quintero in the jail, interviewing him about his life and assembling all available social history records from Texas and Mexico, they went to Celaya, the small Mexican city where Quintero was raised. There they discovered that Quintero, at the age of six, had suffered a significant head injury when he fell off the roof of his house. As a result of the head trauma, he developed a seizure disorder. His friend called him Nopal ("Cactus") because he would often just stare off into space. A mental health evaluation and neuroimaging confirmed

\footnotetext{
${ }^{1}$ Jeffrey Toobin, The Mitigator: A New Way of Looking at the Death Penalty, New Yorker (May 9, 2011), http:// www.newyorker.com/magazine/2011/05/09/the-mitigator. Since most of the following description came from either Toobin's article or discussions with the defense team, we cite only the article here.
} 
the brain damage and seizure disorder. Interviews with other family members and friends uncovered that despite coming from a relatively intact family (one of his sisters was a nun and one of his brothers was an engineer), Quintero had been physically and emotionally abused by his father, suffered from depression and anxiety, and was genetically predisposed to alcoholism.

From these pieces of evidence-these data bits-the defense team was able to paint a credible picture of a damaged man who "snapped" in a way that would likely never happen again. They emphasized his strengths, that he was a good brother, husband, and father, but also acknowledged that he was someone capable of committing a terrible act. In sum, the defense team humanized Quintero and contextualized his crime. Ten jurors voted for life without parole, and Quintero avoided execution.

We could tell countless other mitigation life stories in challenging cases. In 2015, a powerful mitigation narrative persuaded a jury not to impose the death penalty on Joseph McEnroe, who was convicted of six (yes, six) counts of capital murder for killing three generations of his then-girlfriend's family who were gathered for a holiday celebration at the girlfriend's parents' home in King County, Washington. ${ }^{2}$ Brian Nichols - the Atlanta Courthouse killer-avoided a death sentence because of his defense team's meticulous gathering and packaging of the available mitigating evidence. ${ }^{3}$ There are many other cases in which the investigation and development of mitigation resulted in life sentences even though the pundits were convinced that death was inevitable. Ted Kaczynski ${ }^{4}$ and Jared Loughner ${ }^{5}$ come readily to mind. The bottom line in all such cases is that mitigation matters. Mitigation works. It is all too often the difference between life and death. And that is the reason for this book.

\section{The Importance of "Changing the Story"}

Why does mitigation matter? The reality is that most of our clients are guilty of an offense punishable by death. Not all of them are guilty, of course. Between 1973 and 2016, nearly 160 inmates who were sentenced to death have been exonerated—a reminder that

\footnotetext{
${ }^{2}$ Jennifer Sullivan \& Steve Miletich, Split Jury Spares Carnation Killer McEnroe from Death, SEATtLe Times, May 14, 2015.

${ }^{3}$ CNN, Jury Spares Nichols a Death Sentence (Dec. 12, 2008), http://www.cnn.com/2008/CRIME/12/12/ nichols.sentence/index.html?eref=rss_latest.

${ }^{4}$ William Glaberson, The Unabomber Case: The Overview; Kaczynski Avoids Death Sentence with Guilty Plea, N.Y. Times (Jan. 23, 1998), http://www.nytimes.com/1998/01/23/us/unabomber-case-overview-kaczynskiavoids-death-sentence-with-guilty-plea.html. For importance of mitigation investigation in negotiated dispositions, see infra note 7.

${ }^{5}$ Fernanda Santos, Life Term for Gunman After Guilty Plea in Tucson Killings, N.Y. Times (Aug. 8, 2012), http://www.nytimes.com/2012/08/08/us/loughner-pleads-guilty-in-2011-tucson-shootings.html?_r=0. For importance of mitigation investigation in negotiated dispositions, see infra note 7.
} 
some of our clients may indeed be innocent. ${ }^{6}$ It is also true that many of our clients did not do exactly what (or everything that) the prosecution says they did. But if there is a capital trial (which should be avoided if at all possible), ${ }^{7}$ most defendants are going to be found guilty of a capital offense, and the jury is going to make the decision between life and death.

A capital trial, like all other forms of litigation, is a battle of competing stories. ${ }^{8}$ In most capital cases, the prosecution's case for death unfolds in a predictable manner. It proceeds more or less like this: (1) The defendant committed a horrible crime that disrupted the moral fabric of this community; (2) the crime the defendant committed (and any past crimes the defendant may have committed) tells you all you need to know about this person's true character: the defendant is not like us but is a remorseless killing machine; (3) you must impose the death penalty to protect society, to ensure the defendant pays just consequences for committing the crime, and to restore moral order to the community. We term this predictable process the "prosecution's dehumanizing melodrama of death," and virtually every prosecutor's case for death follows this familiar, well-worn path. ${ }^{\text {? }}$

A comprehensive, credible mitigation case is necessary to offset the prosecution's narrative. Unless the capital defense team can humanize their client and contextualize the

\footnotetext{
${ }^{6}$ See Death Penalty Information Center website, http://www.deathpenaltyinfo.org/innocence-and-deathpenalty, last visited Jan. 25, 2017 (including death row exoneration of Alfred Brown on June 8, 2015). This is not to forget individuals such as Cameron Todd Willingham and Carlos Deluna who were executed despite almost certainly being innocent. See David Grann, Trial by Fire: Did Texas Execute an Innocent Man, New Yorker (Sept. 7, 2009), http://www.newyorker.com/magazine/2009/09/07/trial-by-fire; JAMES S. LiEBMAN \& the Columbia Deluna Project, The Wrong Carlos: Anatomy of a Wrongful Execution (2014).

${ }^{7}$ Tragically, our best estimate is that the majority of persons currently on death row rejected a plea bargain that would have allowed them to plead guilty in exchange for a life sentence or, in some cases, a term of years. See Russell Stetler, Commentary on Counsel's Duty to Seek and Negotiate a Disposition in Capital Cases (ABA Guideline 10.9.1), 31 Hofstra L. Rev. 1157 (2003) ("Pleas have been available in the overwhelming majority of capital cases in the post-Furman era, including the cases of hundreds of prisoners who have been executed"); John H. Blume, Plea Bargaining and the Right to the Effective Assistance of Counsel: Where the Rubber Hits the Road in Capital Cases, 25 Fed. Sentencing Rptr. 2 (Dec. 2012) (noting that approximately half of death sentenced inmates rejected plea offers that would have spared their lives). The mitigation investigation is critical to the plea process in identifying individuals who care whether the client lives or dies, finding the family members and loved ones who can help the client grapple with the most difficult decision a criminal defendant is ever called upon to make, and assuring the client that these loved ones will visit, take his phone calls, and subsidize his commissary account twenty years into the future.

${ }^{8}$ See John H. Blume, Sheri L. Johnson and Emily C. Paavola, Every Juror Wants a Story: Narrative Relevance, Third Party Guilt o the Right to Present a Defense, 44 Am. Crim. L. Rev. 1069, 1089 (2007). See also, generally, Anthony G. Amsterdam \& Philip N. Meyer, Making Our Clients' Stories Heard (2008); Death Penalty Stories (John H. Blume \& Jordan M. Steiker, eds., 2009); Sean D. O’Brien, Symposium: Death Penalty Stories, 77 UMKC L. Rev. 831 (2009).

'See also Craig Haney's discussion of the "master crime narrative" and the "myth of demonic agency" in The Social Context of Capital Murder: Social Histories and the Logic of Mitigation, 35 Santa Clara L. Rev. 547 (1995); Media Criminology and the Death Penalty, 58 DePaul L. Rev. 689 (2009); and On Mitigation as Counter-Narrative: A Case Study of the Hidden Context of Prison Violence, 77 UMKC L. Rev. 911 (2009).
} 
crime in a manner the jury finds persuasive, the prosecution's story will almost certainly prevail. We refer to this defense effort as "changing the narrative" or "creating a story for life." As we discuss in more detail later in this chapter, and is discussed elsewhere in this volume, ${ }^{10}$ changing the narrative requires more than simply gathering mitigating evidence. The collection of information is a necessary, but not a sufficient, condition to presenting a persuasive case for life. When we began our capital defense careers, we routinely saw postconviction cases in which virtually (or sometimes literally) no mitigation investigation was done at trial. The defense team did not engage a mitigation specialist, gather any records, or interview any witnesses (except maybe the client's mother), and thus the case for life was either nonexistent or involved only a family member or two. Those days, for the most part, are thankfully behind us. What we do see, with increasing frequency, are cases in which the mitigation "basics" were complied with, but the case for life fell on deaf ears because it was not presented persuasively. In some of the cases in this category, the defense team had a mitigation specialist who conducted numerous interviews, gathered social history records, and consulted one or more mental health experts. Still, because of a failure to package the information in a way that humanized the client and placed the crime in the appropriate context given the client's life story, the prosecution's melodrama of death prevailed. We return to this theme later in this chapter. But first, let us consider what mitigation is—and is not.

\section{Mitigation Has Virtually No Limits and Is Potentially Infinite}

There are three ways of defining and understanding what mitigation is: the statutory guidance, the Supreme Court's Eighth Amendment jurisprudence, and the empirical social science evidence of what actually inspires mercy and empathy on the part of death-qualified jurors. The least helpful—and most confusing — approach comes from the statutory frameworks.

At its peak in the post-Furman era, ${ }^{11}$ capital punishment was an option in thirty-eight states as well as in federal and military prosecutions, and there are multiple statutory definitions of mitigation. Some capital statutes fail to define mitigating factors at all, ${ }^{12}$ but typically they list mitigating factors such as age at the time of the crime and the absence of a significant history of prior criminal convictions. Many statutory factors focus on the circumstances of the crime (victim participation or consent, relatively minor participation, duress or domination) or the defendant's mental state at the time

\footnotetext{
${ }^{10}$ See, e.g., Stephen B. Bright, Chapter 12, “Telling the Client's Story: Developing a Consistent Theme for Life Imprisonment without Possibility of Parole," in this book.

${ }^{11}$ Furman v. Georgia, 408 U.S. 238, 239-40 (1972) (finding death penalty arbitrary and unconstitutional as applied when jurors had unfettered discretion to impose it).

${ }^{12}$ See, e.g., Del. Code Ann. tit. $11 \$ 4209$ (2006); Ga. Code Ann. $\$ 17-10-30$ (2007); Idaho Code Ann. $\$$ 19.2515; Or. Rev. Stat. Ann. $\$ 163.150$ (West 2007); S.D. Codified Laws $\$ 23 A-27 A-1$ (2007); Tex. Code Crim. Proc. Ann. art. 37.071 (Vernon 2007).
} 
of the crime (extreme mental or emotional disturbance, impaired capacity to appreciate right from wrong or conform one's conduct) while making clear that the mitigating mental conditions do not rise to the level of an affirmative defense. ${ }^{13}$ Some statutes include broad language to cover "any other" mitigating circumstances, ${ }^{14}$ but often with no guidance beyond the magic word itself: mitigation.

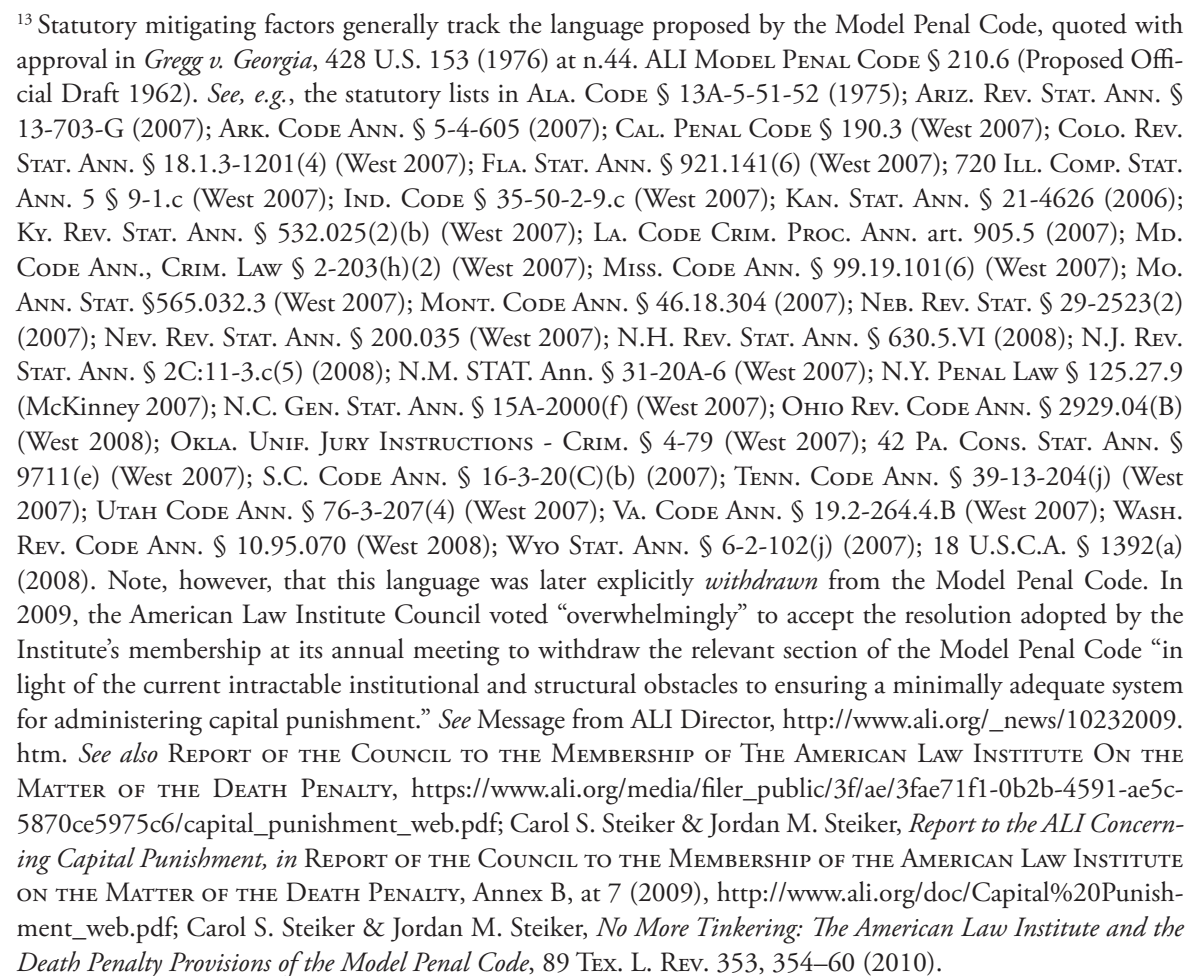

${ }^{14}$ See Ala. Code $\$ 13$ A-52 (1975): "In addition to the mitigating circumstances specified in Section 13A5-51, mitigating circumstances shall include any aspect of a defendant's character or record and any of the circumstances of the offense that the defendant offers as a basis for a sentence of life imprisonment without parole instead of death, and any other relevant mitigating circumstance which the defendant offers as a basis for a sentence of life imprisonment without parole instead of death." CAL. Penal Code $\$ 190.3(\mathrm{k})$ : "Any other circumstance which extenuates the gravity of the crime even though it is not a legal excuse for the crime." Colo. Rev. Stat. Ann. $\$ 18.1 .3-1201(4)(1)$ : "Any other evidence which in the court's opinion bears on the question of mitigation.” IND. CODE $\$ 35-50-2-9 . c .8$ : "Any other circumstance appropriate for consideration." La. Code Crim. Proc. Ann. art. 905.5(h): "Any other relevant mitigating circumstance.” Md. Code Ann.,

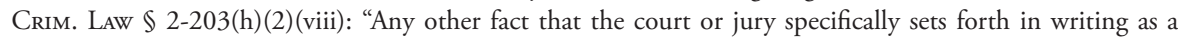
mitigating circumstance in the case.” Mont. Code AnN. $\$ 46.18 .304(2)$ : “The court may consider any other fact that exists in mitigation of the penalty." Nev. Rev. Stat. Ann. $\$$ 200.035.7: "Any other mitigating circumstance." N.H. Rev. Stat. Ann. $\$$ 630.5.VI(i): "Other factors in the defendant's background or character mitigate against imposition of the death sentence.” N.J. Rev. Stat. Ann. \$2C:11-3.c(5)(h): “Any other factor which is relevant to the defendant's character or record or to the circumstances of the offense." N.Y. PENAL LaW $\$ 125.27 .9(\mathrm{f})$ : “Any other circumstance concerning the crime, the defendant's state of mind or condition at 
Sadly, the statutory frameworks have tended only to confuse lawyers, judges, and jurors. They have tended to obscure the fundamental point that mitigation has no boundaries under the Eighth Amendment requirement of individualized selection for society's punishment of last resort. ${ }^{15}$ The breadth of mitigating evidence has been clear since the Supreme Court rejected the mandatory sentencing statutes enacted in Louisiana and North Carolina ${ }^{16}$ and established that individualized sentencing is a constitutional requirement when the punishment is death. In Woodson v. North Carolina, the Court held:

A process that accords no significance to relevant facets of the character and record of the individual offender or the circumstances of the particular offense excludes from consideration in fixing the ultimate punishment of death the possibility of compassionate or mitigating factors stemming from the diverse frailties of humankind. It treats all persons convicted of a designated offense not as uniquely individual human beings, but as members of a faceless, undifferentiated mass to be subjected to the blind infliction of the penalty of death.

While the prevailing practice of individualizing sentencing determinations generally reflects simply enlightened policy rather than a constitutional imperative, we believe that in capital cases the fundamental respect for humanity underlying the Eighth Amendment . . . requires consideration of the character and record of the individual offender and the circumstances of the particular offense as a constitutionally indispensable part of the process of inflicting the penalty of death. ${ }^{17}$

the time of the crime, or the defendant's character, background or record that would be relevant to mitigation or punishment for the crime." N.C. Gen. Stat. AnN. \$15A-2000(f)(9): "Any other circumstance arising from the evidence which the jury deems to have mitigating value." Ohio Rev. Code Ann. \$2929.04(B)(7): "Any other factors that are relevant to the issue of whether the offender should be sentenced to death." OKLA. UNIf. JURY INSTRUCTIONS-CRIM. \$4-79: "In addition, you may decide that other mitigating circumstances exist, and if so, you should consider those circumstances as well." 42 Pa. Cons. Stat. Ann. \$9711(e)(8): "Any other evidence of mitigation concerning the character and record of the defendant and the circumstances of the offense." Tenn. Code. Ann. \$39-13-204(j)(9): "Any other mitigating factor that is raised by the evidence produced by either the prosecution or defense, at either the guilt or sentencing hearing." UTAH Code. AnN. $\$$ 76-3-207(4)(g): "Any other fact in mitigation of penalty." Wyo. STAT. AnN. \$ 6-2-102(j)(viii): “Any other fact or circumstance of the defendant's character or prior record or matter surrounding his offense which serves to mitigate his culpability." 18 U.S.C.A. $\$ 1392$ (a)(8): "Other factors in the defendant's background, record, or character or any other circumstance of the offense that mitigate against imposition of the death penalty."

${ }^{15}$ Since the mid-1970s, the U.S. Supreme Court has distinguished between the eligibility phase of capital cases (i.e., which classes of murder are "eligible" for the death penalty), where the post-Furman jury's discretion must be channeled and limited to "ensure that the death penalty is a proportionate punishment and therefore not arbitrary or capricious in its imposition," and the selection phase (i.e., which defendants will be sentenced to death), where the Supreme Court requires "a broad inquiry into all relevant mitigating evidence to allow an individualized determination." See Buchanan v. Angelone, 522 U.S. 269, 275-6 (1998).

${ }^{16}$ Roberts v. Louisiana, 428 U.S. 325 (1976); Woodson v. North Carolina, 428 U.S. 280 (1976).

${ }^{17}$ Woodson, 428 U.S. at 303-04. 
Thus, in 1976, the Court began defining what constitutes mitigation, and it did so in the broadest conceivable terms — speaking of the "diverse frailties of humankind" as the source of mercy and empathy. Decades earlier, the writer Arthur Koestler spoke of the "shuddering recognition of a kinship" that evokes the response "here but for the grace of God hang I" in the face of a condemned prisoner at the gallows. ${ }^{18}$ The diverse frailties bestow the kinship of humanity. We all have them, to varying degrees. For most of us, the frailties are offset by the protective supports of family and society as well as by our individual strengths. For many capital clients, however, the frailties are overwhelming, and the supports are absent. Eighth Amendment jurisprudence confers compensatory protection to allow life-or-death decision makers to extend compassion on an individual basis. ${ }^{19}$

In 1978, Sandra Lockett challenged the constitutionality of the Ohio capital statute, claiming it did not allow the sentencing judge to consider as mitigating factors her character, prior record, age, lack of specific intent to cause death, and relatively minor role in the crime. In Lockett v. Ohio, ${ }^{20}$ the Court concluded that the Eighth and Fourteenth Amendments require that the sentencer "not be precluded from considering, as a mitigating factor, any aspect of a defendant's character or record and any of the circumstances of the offense that the defendant proffers as a basis for a sentence less than death." ${ }^{21}$

Guidance from the Supreme Court has also stressed the importance of understanding what shaped capital clients in their developmental years. Monty Lee Eddings was sixteen when he killed an Oklahoma Highway Patrol officer. ${ }^{22}$ He was certified to stand trial as an adult and pled nolo contendere in the district court. ${ }^{23}$ Evidence of aggravating and mitigating circumstances was presented to the trial judge, including extreme violence inflicted by his father and the young man's emotional disturbance, but the judge stated that the court, "in following the law," could not "consider the fact of this young man's violent background." ${ }^{24}$ Following the rule announced in Lockett v. Ohio, ${ }^{25}$ the High Court reversed, holding that capital sentencers may not exclude mitigating evidence from their consideration: ${ }^{26}$

We find that the limitations placed by these courts upon the mitigating evidence they would consider violated the rule in Lockett. Just as the state may not by statute preclude

\footnotetext{
${ }^{18}$ As quoted in Witherspoon v. Illinois, 391 U.S. 510, 520 (1968), n.17, Arthur Koestler, Reflections on Hanging 166-67 (1956).

${ }^{19}$ See Russell Stetler \& Kathleen Wayland, Dimensions of Mitigation, Champion 31 (June 2004) (discussing how mitigation is inherently dimensional, rather than categorical).

${ }^{20} 438$ U.S. 586 (1978).

${ }^{21} \mathrm{Id}$. at 604 .

${ }^{22}$ Eddings v. Oklahoma, 455 U.S. 104, 105-06 (1982). An amicus curiae brief was filed by M. Gail Robinson, Kevin M. McNally, and J. Vincent Aprile II for Kentucky Youth Advocates et al. Id. at 105 n.*.

${ }^{23} \mathrm{Id}$. at 106.

${ }^{24} \mathrm{Id}$. at $107-09$.

${ }^{25} 438$ U.S. at 616-17 (1978) (finding that sentencing authorities may consider mitigating circumstances).

${ }^{26}$ Eddings, 455 U.S. at 114-15.
} 
the sentencer from considering any mitigating factor, neither may the sentencer refuse to consider, as a matter of law, any relevant mitigating evidence. ${ }^{27}$

The opinion is eloquent in distinguishing responsibility from punishment and culpability considerations, as the Court went on to discuss the special mitigating qualities of youth and the vulnerability of the developmental years:

The trial judge recognized that youth must be considered a relevant mitigating factor. But youth is more than a chronological fact. It is a time and condition of life when a person may be most susceptible to influence and to psychological damage. Our history is replete with laws and judicial recognition that minors, especially in their earlier years, generally are less mature and responsible than adults. Particularly "during the formative years of childhood and adolescence, minors often lack the experience, perspective, and judgment" expected of adults. Even the normal 16-year-old customarily lacks the maturity of an adult. In this case, Eddings was not a normal 16-year-old; he had been deprived of the care, concern, and paternal attention that children deserve. On the contrary, it is not disputed that he was a juvenile with serious emotional problems, and had been raised in a neglectful, sometimes even violent, family background. In addition, there was testimony that Eddings' mental and emotional development were at a level several years below his chronological age. All of this does not suggest an absence of responsibility for the crime of murder, deliberately committed in this case. Rather, it is to say that just as the chronological age of a minor is itself a relevant mitigating factor of great weight, so must the background and mental and emotional development of a youthful defendant be duly considered in sentencing. ${ }^{28}$

Mitigating evidence cannot even be limited to the preoffense time frame. It can embrace redemption and postoffense "good adjustment" in jail. In Skipper v. South Carolina ${ }^{29}$ the Court held that the defense should have been permitted to introduce such evidence at trial even though it "would not relate specifically to petitioner's culpability for the crime he committed" because "there is no question but that such inferences would be 'mitigating' in the sense that they might serve as a basis for a sentence less than death." ${ }^{30}$ The Skipper Court succinctly defined mitigation as "anything which might lead a reasonable juror to conclude that life is the appropriate punishment." ${ }^{\text {"1 }}$

Justice O'Connor went on in Penry v. Lynaugh ${ }^{32}$ to reaffirm "the principle that punishment should be directly related to the personal culpability of the criminal defendant"

\footnotetext{
${ }^{27} \mathrm{Id}$. at $113-14$.

${ }^{28} \mathrm{Id}$. at $115-16$.

${ }^{29} 476$ U.S. 1 (1986).

${ }^{30} \mathrm{Id}$. at $4-5$.

${ }^{31} I d$. at 6 .

32492 U.S. 302 (1989).
} 
in capital cases. ${ }^{33}$ She stated, "Rather than creating a risk of an unguided emotional response, full consideration of evidence that mitigates against the death penalty is essential if the jury is to give a 'reasoned moral response to the defendant's background, character, and crime."'34

In this century, the High Court has reiterated its fundamental insistence on the breadth of mitigating evidence. In Tennard $v$. Dretke, ${ }^{35}$ the Court stressed that there is a "low threshold for relevance" in the mitigation context and "virtually no limits are placed on the relevant mitigating evidence a capital defendant may introduce concerning his own circumstances." ${ }^{36}$ The Court also reminded the Texas courts that mitigation requires no "nexus" to the crime, noting that some circumstances, such as impaired intellectual functioning, are "inherently mitigating." ${ }^{37}$ In Ayers $v$. Belmontes, ${ }^{38}$ Justice Kennedy contrasted "the finite aggravators against the potentially infinite mitigators." ${ }^{3}$ Finally, in Kennedy $v$. Louisiana, ${ }^{40}$ the Court offered a pithy summary of eligibility and selection once again: capital punishment must "be limited to those offenders who 'commit a narrow category of the most serious crimes' and whose extreme culpability makes them 'the most deserving of execution."'41

Our practical understanding of mitigation is also informed by a robust body of empirical social science research explicating how jurors make life-or-death decisions in the selection phase of capital trials. ${ }^{42}$ The Capital Jury Project (CJP) was initiated in 1991 by a consortium of university-based researchers with support from the National

\footnotetext{
${ }^{33} \mathrm{Id}$. at 319.

${ }^{34}$ Id. at 328, quoting California v. Brown, 479 U.S. 538, 545 (1987). Professor Joan W. Howarth developed this analysis of the reasoned moral response in her study of the role of gender in capital juries. Joan W. Howarth, Deciding to Kill: Revealing the Gender in the Task Handed to Capital Juries, 6 WIs. L. Rev. 1345 (1994). She stressed the need for personalized responsibility and individualized, contextualized decision making in sentencing determinations. Howarth contrasted the jury's fact-finding role in guilt trials, based on the traditional ethic of justice, with its moral role in penalty trials, based on an ethic of caring, compassion, and mercy. She found a hidden battleground of gender in capital juries— pitting rational versus irrational, active versus passive, thought versus feeling, objective versus subjective, abstract versus contextualized, distance versus connection, rules versus context, anger versus pity. Perhaps the most fundamental point is that there is simply no objective test, no rule to measure mitigation, no scale to quantify empathy-evoking evidence.

${ }^{35} 543$ U.S. 274 (2004).

${ }^{36}$ Id. at 285, quoting Eddings, supra note 22, at 114 . The Court also cited the relevance standard it had addressed directly in McKoy v. North Carolina, 494 U.S. 433, 440-441 (1990), where a state court dissent had been quoted with approval: "Relevant mitigating evidence is evidence which tends logically to prove or disprove some fact or circumstances which a fact-finder could reasonably deem to have mitigating value." Id. at 440 (quoting State v. McKoy, 372 S.E.2d 12, 45 [N.C. 1988]).

${ }^{37}$ Tennard, 543 U.S. at 287.

${ }^{38} 549$ U.S. 7 (2006).

${ }^{39} \mathrm{Id}$. at 21.

40554 U.S. 407 (2008).

${ }^{41} \mathrm{Id}$. at 420. Citations omitted.

${ }^{42}$ See Marla Sandys, Elizabeth S. Vartkessian, Heather Pruss, \& Sara M. Walsh, Chapter 4, "Setting the Stage and Listening to What Jurors Have to Tell Us about Mitigation" (drawing on their personal experience in Capital Jury Project research).
} 


\section{Mitigation Matters}

John Blume and Russell Stetler

\section{Introduction}

Mitigation matters. It works. It literally saves lives every day, often in cases in which a death sentence seems a foregone conclusion. But mitigation matters-it works_-only if the capital defense team is committed both to conducting a comprehensive investigation of the client's life and to developing and integrating the results of the investigation into a compelling, credible narrative for life. This commitment to uncovering and telling the client's true story must be complete and unwavering. When it is, life sentences follow. When it is not, undeserved death sentences are imposed.

Mitigation made this precise difference in Juan Quintero's case. Quintero was charged with the murder of Rodney Johnson, a decorated veteran Houston police officer. ${ }^{1}$ After a traffic stop, Johnson arrested Quintero when he could not produce a driver's license or any other form of identification. Johnson frisked Quintero but somehow missed a 9-mm pistol Quintero had hidden in the waistband of his pants. Although his hands were cuffed behind his back, Quintero managed to get the gun out of his pants, turn, and shoot Johnson seven times. To make matters worse, Quintero was in the country illegally; he had been deported back to Mexico years earlier after pleading guilty to sexually assaulting a twelve-year-old girl.

Quintero's team did not despair that their client was charged with killing a cop in death-friendly Harris County, the buckle of the Texas death belt. Instead, they rolled up their sleeves and went to work. After spending numerous hours with Quintero in the jail, interviewing him about his life and assembling all available social history records from Texas and Mexico, they went to Celaya, the small Mexican city where Quintero was raised. There they discovered that Quintero, at the age of six, had suffered a significant head injury when he fell off the roof of his house. As a result of the head trauma, he developed a seizure disorder. His friend called him Nopal ("Cactus") because he would often just stare off into space. A mental health evaluation and neuroimaging confirmed

\footnotetext{
${ }^{1}$ Jeffrey Toobin, The Mitigator: A New Way of Looking at the Death Penalty, New Yorker (May 9, 2011), http:// www.newyorker.com/magazine/2011/05/09/the-mitigator. Since most of the following description came from either Toobin's article or discussions with the defense team, we cite only the article here.
} 
the brain damage and seizure disorder. Interviews with other family members and friends uncovered that despite coming from a relatively intact family (one of his sisters was a nun and one of his brothers was an engineer), Quintero had been physically and emotionally abused by his father, suffered from depression and anxiety, and was genetically predisposed to alcoholism.

From these pieces of evidence-these data bits-the defense team was able to paint a credible picture of a damaged man who "snapped" in a way that would likely never happen again. They emphasized his strengths, that he was a good brother, husband, and father, but also acknowledged that he was someone capable of committing a terrible act. In sum, the defense team humanized Quintero and contextualized his crime. Ten jurors voted for life without parole, and Quintero avoided execution.

We could tell countless other mitigation life stories in challenging cases. In 2015, a powerful mitigation narrative persuaded a jury not to impose the death penalty on Joseph McEnroe, who was convicted of six (yes, six) counts of capital murder for killing three generations of his then-girlfriend's family who were gathered for a holiday celebration at the girlfriend's parents' home in King County, Washington. ${ }^{2}$ Brian Nichols - the Atlanta Courthouse killer-avoided a death sentence because of his defense team's meticulous gathering and packaging of the available mitigating evidence. ${ }^{3}$ There are many other cases in which the investigation and development of mitigation resulted in life sentences even though the pundits were convinced that death was inevitable. Ted Kaczynski ${ }^{4}$ and Jared Loughner ${ }^{5}$ come readily to mind. The bottom line in all such cases is that mitigation matters. Mitigation works. It is all too often the difference between life and death. And that is the reason for this book.

\section{The Importance of "Changing the Story"}

Why does mitigation matter? The reality is that most of our clients are guilty of an offense punishable by death. Not all of them are guilty, of course. Between 1973 and 2016, nearly 160 inmates who were sentenced to death have been exonerated—a reminder that

\footnotetext{
${ }^{2}$ Jennifer Sullivan \& Steve Miletich, Split Jury Spares Carnation Killer McEnroe from Death, SEATtLe Times, May 14, 2015.

${ }^{3}$ CNN, Jury Spares Nichols a Death Sentence (Dec. 12, 2008), http://www.cnn.com/2008/CRIME/12/12/ nichols.sentence/index.html?eref=rss_latest.

${ }^{4}$ William Glaberson, The Unabomber Case: The Overview; Kaczynski Avoids Death Sentence with Guilty Plea, N.Y. Times (Jan. 23, 1998), http://www.nytimes.com/1998/01/23/us/unabomber-case-overview-kaczynskiavoids-death-sentence-with-guilty-plea.html. For importance of mitigation investigation in negotiated dispositions, see infra note 7.

${ }^{5}$ Fernanda Santos, Life Term for Gunman After Guilty Plea in Tucson Killings, N.Y. Times (Aug. 8, 2012), http://www.nytimes.com/2012/08/08/us/loughner-pleads-guilty-in-2011-tucson-shootings.html?_r=0. For importance of mitigation investigation in negotiated dispositions, see infra note 7.
} 
some of our clients may indeed be innocent. ${ }^{6}$ It is also true that many of our clients did not do exactly what (or everything that) the prosecution says they did. But if there is a capital trial (which should be avoided if at all possible), ${ }^{7}$ most defendants are going to be found guilty of a capital offense, and the jury is going to make the decision between life and death.

A capital trial, like all other forms of litigation, is a battle of competing stories. ${ }^{8}$ In most capital cases, the prosecution's case for death unfolds in a predictable manner. It proceeds more or less like this: (1) The defendant committed a horrible crime that disrupted the moral fabric of this community; (2) the crime the defendant committed (and any past crimes the defendant may have committed) tells you all you need to know about this person's true character: the defendant is not like us but is a remorseless killing machine; (3) you must impose the death penalty to protect society, to ensure the defendant pays just consequences for committing the crime, and to restore moral order to the community. We term this predictable process the "prosecution's dehumanizing melodrama of death," and virtually every prosecutor's case for death follows this familiar, well-worn path. ${ }^{\text {? }}$

A comprehensive, credible mitigation case is necessary to offset the prosecution's narrative. Unless the capital defense team can humanize their client and contextualize the

\footnotetext{
${ }^{6}$ See Death Penalty Information Center website, http://www.deathpenaltyinfo.org/innocence-and-deathpenalty, last visited Jan. 25, 2017 (including death row exoneration of Alfred Brown on June 8, 2015). This is not to forget individuals such as Cameron Todd Willingham and Carlos Deluna who were executed despite almost certainly being innocent. See David Grann, Trial by Fire: Did Texas Execute an Innocent Man, New Yorker (Sept. 7, 2009), http://www.newyorker.com/magazine/2009/09/07/trial-by-fire; JAMES S. LiEBMAN \& the Columbia Deluna Project, The Wrong Carlos: Anatomy of a Wrongful Execution (2014).

${ }^{7}$ Tragically, our best estimate is that the majority of persons currently on death row rejected a plea bargain that would have allowed them to plead guilty in exchange for a life sentence or, in some cases, a term of years. See Russell Stetler, Commentary on Counsel's Duty to Seek and Negotiate a Disposition in Capital Cases (ABA Guideline 10.9.1), 31 Hofstra L. Rev. 1157 (2003) ("Pleas have been available in the overwhelming majority of capital cases in the post-Furman era, including the cases of hundreds of prisoners who have been executed"); John H. Blume, Plea Bargaining and the Right to the Effective Assistance of Counsel: Where the Rubber Hits the Road in Capital Cases, 25 Fed. Sentencing Rptr. 2 (Dec. 2012) (noting that approximately half of death sentenced inmates rejected plea offers that would have spared their lives). The mitigation investigation is critical to the plea process in identifying individuals who care whether the client lives or dies, finding the family members and loved ones who can help the client grapple with the most difficult decision a criminal defendant is ever called upon to make, and assuring the client that these loved ones will visit, take his phone calls, and subsidize his commissary account twenty years into the future.

${ }^{8}$ See John H. Blume, Sheri L. Johnson and Emily C. Paavola, Every Juror Wants a Story: Narrative Relevance, Third Party Guilt o the Right to Present a Defense, 44 Am. Crim. L. Rev. 1069, 1089 (2007). See also, generally, Anthony G. Amsterdam \& Philip N. Meyer, Making Our Clients' Stories Heard (2008); Death Penalty Stories (John H. Blume \& Jordan M. Steiker, eds., 2009); Sean D. O’Brien, Symposium: Death Penalty Stories, 77 UMKC L. Rev. 831 (2009).

'See also Craig Haney's discussion of the "master crime narrative" and the "myth of demonic agency" in The Social Context of Capital Murder: Social Histories and the Logic of Mitigation, 35 Santa Clara L. Rev. 547 (1995); Media Criminology and the Death Penalty, 58 DePaul L. Rev. 689 (2009); and On Mitigation as Counter-Narrative: A Case Study of the Hidden Context of Prison Violence, 77 UMKC L. Rev. 911 (2009).
} 
crime in a manner the jury finds persuasive, the prosecution's story will almost certainly prevail. We refer to this defense effort as "changing the narrative" or "creating a story for life." As we discuss in more detail later in this chapter, and is discussed elsewhere in this volume, ${ }^{10}$ changing the narrative requires more than simply gathering mitigating evidence. The collection of information is a necessary, but not a sufficient, condition to presenting a persuasive case for life. When we began our capital defense careers, we routinely saw postconviction cases in which virtually (or sometimes literally) no mitigation investigation was done at trial. The defense team did not engage a mitigation specialist, gather any records, or interview any witnesses (except maybe the client's mother), and thus the case for life was either nonexistent or involved only a family member or two. Those days, for the most part, are thankfully behind us. What we do see, with increasing frequency, are cases in which the mitigation "basics" were complied with, but the case for life fell on deaf ears because it was not presented persuasively. In some of the cases in this category, the defense team had a mitigation specialist who conducted numerous interviews, gathered social history records, and consulted one or more mental health experts. Still, because of a failure to package the information in a way that humanized the client and placed the crime in the appropriate context given the client's life story, the prosecution's melodrama of death prevailed. We return to this theme later in this chapter. But first, let us consider what mitigation is—and is not.

\section{Mitigation Has Virtually No Limits and Is Potentially Infinite}

There are three ways of defining and understanding what mitigation is: the statutory guidance, the Supreme Court's Eighth Amendment jurisprudence, and the empirical social science evidence of what actually inspires mercy and empathy on the part of death-qualified jurors. The least helpful—and most confusing — approach comes from the statutory frameworks.

At its peak in the post-Furman era, ${ }^{11}$ capital punishment was an option in thirty-eight states as well as in federal and military prosecutions, and there are multiple statutory definitions of mitigation. Some capital statutes fail to define mitigating factors at all, ${ }^{12}$ but typically they list mitigating factors such as age at the time of the crime and the absence of a significant history of prior criminal convictions. Many statutory factors focus on the circumstances of the crime (victim participation or consent, relatively minor participation, duress or domination) or the defendant's mental state at the time

\footnotetext{
${ }^{10}$ See, e.g., Stephen B. Bright, Chapter 12, “Telling the Client's Story: Developing a Consistent Theme for Life Imprisonment without Possibility of Parole," in this book.

${ }^{11}$ Furman v. Georgia, 408 U.S. 238, 239-40 (1972) (finding death penalty arbitrary and unconstitutional as applied when jurors had unfettered discretion to impose it).

${ }^{12}$ See, e.g., Del. Code Ann. tit. $11 \$ 4209$ (2006); Ga. Code Ann. $\$ 17-10-30$ (2007); Idaho Code Ann. $\$$ 19.2515; Or. Rev. Stat. Ann. $\$ 163.150$ (West 2007); S.D. Codified Laws $\$ 23 A-27 A-1$ (2007); Tex. Code Crim. Proc. Ann. art. 37.071 (Vernon 2007).
} 
of the crime (extreme mental or emotional disturbance, impaired capacity to appreciate right from wrong or conform one's conduct) while making clear that the mitigating mental conditions do not rise to the level of an affirmative defense. ${ }^{13}$ Some statutes include broad language to cover "any other" mitigating circumstances, ${ }^{14}$ but often with no guidance beyond the magic word itself: mitigation.

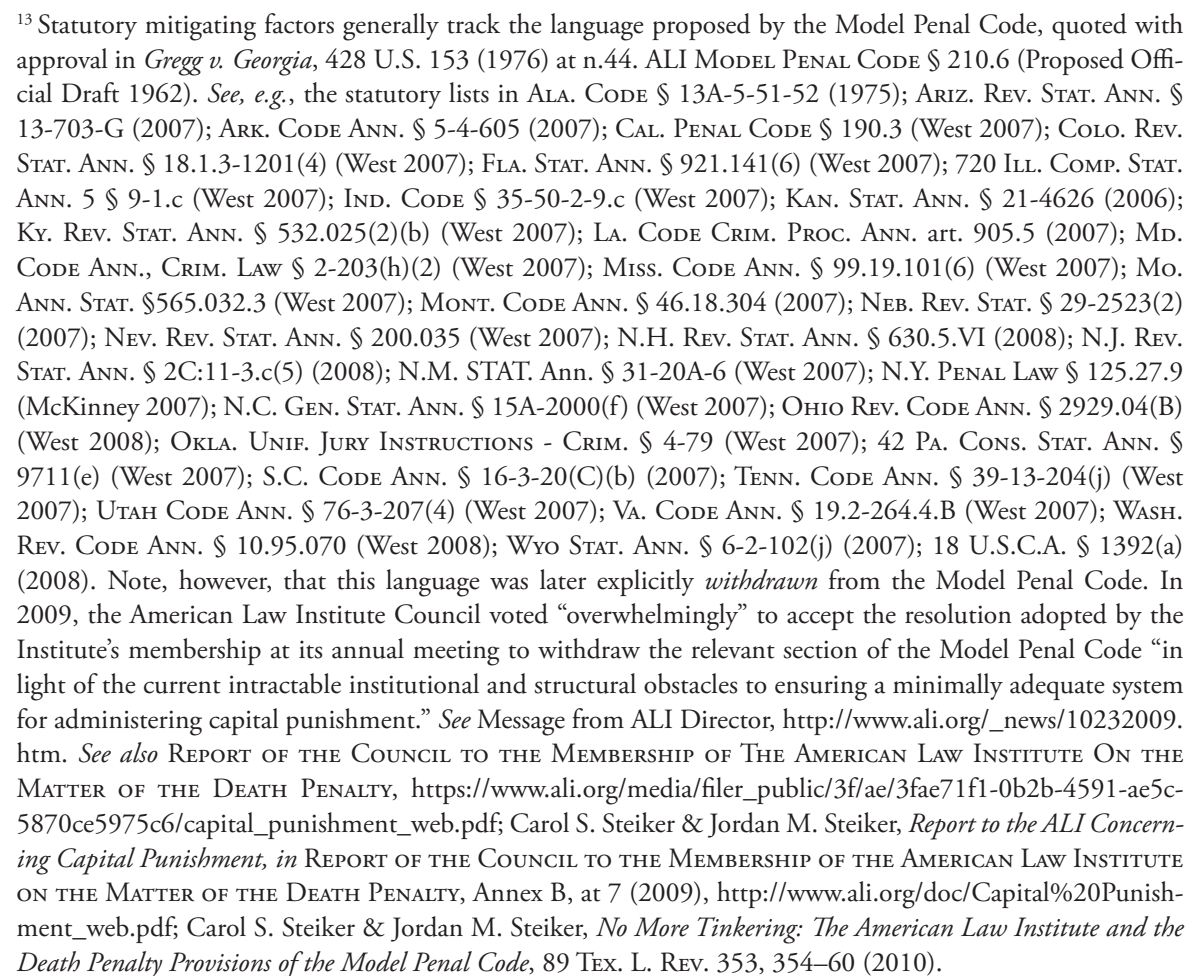

${ }^{14}$ See Ala. Code $\$ 13$ A-52 (1975): "In addition to the mitigating circumstances specified in Section 13A5-51, mitigating circumstances shall include any aspect of a defendant's character or record and any of the circumstances of the offense that the defendant offers as a basis for a sentence of life imprisonment without parole instead of death, and any other relevant mitigating circumstance which the defendant offers as a basis for a sentence of life imprisonment without parole instead of death." CAL. Penal Code $\$ 190.3(\mathrm{k})$ : "Any other circumstance which extenuates the gravity of the crime even though it is not a legal excuse for the crime." Colo. Rev. Stat. Ann. $\$ 18.1 .3-1201(4)(1)$ : "Any other evidence which in the court's opinion bears on the question of mitigation.” IND. CODE $\$ 35-50-2-9 . c .8$ : "Any other circumstance appropriate for consideration." La. Code Crim. Proc. Ann. art. 905.5(h): "Any other relevant mitigating circumstance.” Md. Code Ann.,

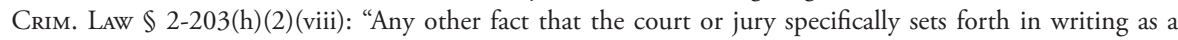
mitigating circumstance in the case.” Mont. Code AnN. $\$ 46.18 .304(2)$ : “The court may consider any other fact that exists in mitigation of the penalty." Nev. Rev. Stat. Ann. $\$$ 200.035.7: "Any other mitigating circumstance." N.H. Rev. Stat. Ann. $\$$ 630.5.VI(i): "Other factors in the defendant's background or character mitigate against imposition of the death sentence.” N.J. Rev. Stat. Ann. \$2C:11-3.c(5)(h): “Any other factor which is relevant to the defendant's character or record or to the circumstances of the offense." N.Y. PENAL LaW $\$ 125.27 .9(\mathrm{f})$ : “Any other circumstance concerning the crime, the defendant's state of mind or condition at 
Sadly, the statutory frameworks have tended only to confuse lawyers, judges, and jurors. They have tended to obscure the fundamental point that mitigation has no boundaries under the Eighth Amendment requirement of individualized selection for society's punishment of last resort. ${ }^{15}$ The breadth of mitigating evidence has been clear since the Supreme Court rejected the mandatory sentencing statutes enacted in Louisiana and North Carolina ${ }^{16}$ and established that individualized sentencing is a constitutional requirement when the punishment is death. In Woodson v. North Carolina, the Court held:

A process that accords no significance to relevant facets of the character and record of the individual offender or the circumstances of the particular offense excludes from consideration in fixing the ultimate punishment of death the possibility of compassionate or mitigating factors stemming from the diverse frailties of humankind. It treats all persons convicted of a designated offense not as uniquely individual human beings, but as members of a faceless, undifferentiated mass to be subjected to the blind infliction of the penalty of death.

While the prevailing practice of individualizing sentencing determinations generally reflects simply enlightened policy rather than a constitutional imperative, we believe that in capital cases the fundamental respect for humanity underlying the Eighth Amendment . . . requires consideration of the character and record of the individual offender and the circumstances of the particular offense as a constitutionally indispensable part of the process of inflicting the penalty of death. ${ }^{17}$

the time of the crime, or the defendant's character, background or record that would be relevant to mitigation or punishment for the crime." N.C. Gen. Stat. AnN. \$15A-2000(f)(9): "Any other circumstance arising from the evidence which the jury deems to have mitigating value." Ohio Rev. Code Ann. \$2929.04(B)(7): "Any other factors that are relevant to the issue of whether the offender should be sentenced to death." OKLA. UNIf. JURY INSTRUCTIONS-CRIM. \$4-79: "In addition, you may decide that other mitigating circumstances exist, and if so, you should consider those circumstances as well." 42 Pa. Cons. Stat. Ann. \$9711(e)(8): "Any other evidence of mitigation concerning the character and record of the defendant and the circumstances of the offense." Tenn. Code. Ann. \$39-13-204(j)(9): "Any other mitigating factor that is raised by the evidence produced by either the prosecution or defense, at either the guilt or sentencing hearing." UTAH Code. AnN. $\$$ 76-3-207(4)(g): "Any other fact in mitigation of penalty." Wyo. STAT. AnN. \$ 6-2-102(j)(viii): “Any other fact or circumstance of the defendant's character or prior record or matter surrounding his offense which serves to mitigate his culpability." 18 U.S.C.A. $\$ 1392$ (a)(8): "Other factors in the defendant's background, record, or character or any other circumstance of the offense that mitigate against imposition of the death penalty."

${ }^{15}$ Since the mid-1970s, the U.S. Supreme Court has distinguished between the eligibility phase of capital cases (i.e., which classes of murder are "eligible" for the death penalty), where the post-Furman jury's discretion must be channeled and limited to "ensure that the death penalty is a proportionate punishment and therefore not arbitrary or capricious in its imposition," and the selection phase (i.e., which defendants will be sentenced to death), where the Supreme Court requires "a broad inquiry into all relevant mitigating evidence to allow an individualized determination." See Buchanan v. Angelone, 522 U.S. 269, 275-6 (1998).

${ }^{16}$ Roberts v. Louisiana, 428 U.S. 325 (1976); Woodson v. North Carolina, 428 U.S. 280 (1976).

${ }^{17}$ Woodson, 428 U.S. at 303-04. 
Thus, in 1976, the Court began defining what constitutes mitigation, and it did so in the broadest conceivable terms — speaking of the "diverse frailties of humankind" as the source of mercy and empathy. Decades earlier, the writer Arthur Koestler spoke of the "shuddering recognition of a kinship" that evokes the response "here but for the grace of God hang I" in the face of a condemned prisoner at the gallows. ${ }^{18}$ The diverse frailties bestow the kinship of humanity. We all have them, to varying degrees. For most of us, the frailties are offset by the protective supports of family and society as well as by our individual strengths. For many capital clients, however, the frailties are overwhelming, and the supports are absent. Eighth Amendment jurisprudence confers compensatory protection to allow life-or-death decision makers to extend compassion on an individual basis. ${ }^{19}$

In 1978, Sandra Lockett challenged the constitutionality of the Ohio capital statute, claiming it did not allow the sentencing judge to consider as mitigating factors her character, prior record, age, lack of specific intent to cause death, and relatively minor role in the crime. In Lockett v. Ohio, ${ }^{20}$ the Court concluded that the Eighth and Fourteenth Amendments require that the sentencer "not be precluded from considering, as a mitigating factor, any aspect of a defendant's character or record and any of the circumstances of the offense that the defendant proffers as a basis for a sentence less than death." ${ }^{21}$

Guidance from the Supreme Court has also stressed the importance of understanding what shaped capital clients in their developmental years. Monty Lee Eddings was sixteen when he killed an Oklahoma Highway Patrol officer. ${ }^{22}$ He was certified to stand trial as an adult and pled nolo contendere in the district court. ${ }^{23}$ Evidence of aggravating and mitigating circumstances was presented to the trial judge, including extreme violence inflicted by his father and the young man's emotional disturbance, but the judge stated that the court, "in following the law," could not "consider the fact of this young man's violent background." ${ }^{24}$ Following the rule announced in Lockett v. Ohio, ${ }^{25}$ the High Court reversed, holding that capital sentencers may not exclude mitigating evidence from their consideration: ${ }^{26}$

We find that the limitations placed by these courts upon the mitigating evidence they would consider violated the rule in Lockett. Just as the state may not by statute preclude

\footnotetext{
${ }^{18}$ As quoted in Witherspoon v. Illinois, 391 U.S. 510, 520 (1968), n.17, Arthur Koestler, Reflections on Hanging 166-67 (1956).

${ }^{19}$ See Russell Stetler \& Kathleen Wayland, Dimensions of Mitigation, Champion 31 (June 2004) (discussing how mitigation is inherently dimensional, rather than categorical).

${ }^{20} 438$ U.S. 586 (1978).

${ }^{21} \mathrm{Id}$. at 604 .

${ }^{22}$ Eddings v. Oklahoma, 455 U.S. 104, 105-06 (1982). An amicus curiae brief was filed by M. Gail Robinson, Kevin M. McNally, and J. Vincent Aprile II for Kentucky Youth Advocates et al. Id. at 105 n.*.

${ }^{23} \mathrm{Id}$. at 106.

${ }^{24} \mathrm{Id}$. at $107-09$.

${ }^{25} 438$ U.S. at 616-17 (1978) (finding that sentencing authorities may consider mitigating circumstances).

${ }^{26}$ Eddings, 455 U.S. at 114-15.
} 
the sentencer from considering any mitigating factor, neither may the sentencer refuse to consider, as a matter of law, any relevant mitigating evidence. ${ }^{27}$

The opinion is eloquent in distinguishing responsibility from punishment and culpability considerations, as the Court went on to discuss the special mitigating qualities of youth and the vulnerability of the developmental years:

The trial judge recognized that youth must be considered a relevant mitigating factor. But youth is more than a chronological fact. It is a time and condition of life when a person may be most susceptible to influence and to psychological damage. Our history is replete with laws and judicial recognition that minors, especially in their earlier years, generally are less mature and responsible than adults. Particularly "during the formative years of childhood and adolescence, minors often lack the experience, perspective, and judgment" expected of adults. Even the normal 16-year-old customarily lacks the maturity of an adult. In this case, Eddings was not a normal 16-year-old; he had been deprived of the care, concern, and paternal attention that children deserve. On the contrary, it is not disputed that he was a juvenile with serious emotional problems, and had been raised in a neglectful, sometimes even violent, family background. In addition, there was testimony that Eddings' mental and emotional development were at a level several years below his chronological age. All of this does not suggest an absence of responsibility for the crime of murder, deliberately committed in this case. Rather, it is to say that just as the chronological age of a minor is itself a relevant mitigating factor of great weight, so must the background and mental and emotional development of a youthful defendant be duly considered in sentencing. ${ }^{28}$

Mitigating evidence cannot even be limited to the preoffense time frame. It can embrace redemption and postoffense "good adjustment" in jail. In Skipper v. South Carolina ${ }^{29}$ the Court held that the defense should have been permitted to introduce such evidence at trial even though it "would not relate specifically to petitioner's culpability for the crime he committed" because "there is no question but that such inferences would be 'mitigating' in the sense that they might serve as a basis for a sentence less than death." ${ }^{30}$ The Skipper Court succinctly defined mitigation as "anything which might lead a reasonable juror to conclude that life is the appropriate punishment." ${ }^{\text {"1 }}$

Justice O'Connor went on in Penry v. Lynaugh ${ }^{32}$ to reaffirm "the principle that punishment should be directly related to the personal culpability of the criminal defendant"

\footnotetext{
${ }^{27} \mathrm{Id}$. at $113-14$.

${ }^{28} \mathrm{Id}$. at $115-16$.

${ }^{29} 476$ U.S. 1 (1986).

${ }^{30} \mathrm{Id}$. at $4-5$.

${ }^{31} I d$. at 6 .

32492 U.S. 302 (1989).
} 
in capital cases. ${ }^{33}$ She stated, "Rather than creating a risk of an unguided emotional response, full consideration of evidence that mitigates against the death penalty is essential if the jury is to give a 'reasoned moral response to the defendant's background, character, and crime."'34

In this century, the High Court has reiterated its fundamental insistence on the breadth of mitigating evidence. In Tennard $v$. Dretke, ${ }^{35}$ the Court stressed that there is a "low threshold for relevance" in the mitigation context and "virtually no limits are placed on the relevant mitigating evidence a capital defendant may introduce concerning his own circumstances." ${ }^{36}$ The Court also reminded the Texas courts that mitigation requires no "nexus" to the crime, noting that some circumstances, such as impaired intellectual functioning, are "inherently mitigating." ${ }^{37}$ In Ayers $v$. Belmontes, ${ }^{38}$ Justice Kennedy contrasted "the finite aggravators against the potentially infinite mitigators." ${ }^{3}$ Finally, in Kennedy $v$. Louisiana, ${ }^{40}$ the Court offered a pithy summary of eligibility and selection once again: capital punishment must "be limited to those offenders who 'commit a narrow category of the most serious crimes' and whose extreme culpability makes them 'the most deserving of execution."'41

Our practical understanding of mitigation is also informed by a robust body of empirical social science research explicating how jurors make life-or-death decisions in the selection phase of capital trials. ${ }^{42}$ The Capital Jury Project (CJP) was initiated in 1991 by a consortium of university-based researchers with support from the National

\footnotetext{
${ }^{33} \mathrm{Id}$. at 319.

${ }^{34}$ Id. at 328, quoting California v. Brown, 479 U.S. 538, 545 (1987). Professor Joan W. Howarth developed this analysis of the reasoned moral response in her study of the role of gender in capital juries. Joan W. Howarth, Deciding to Kill: Revealing the Gender in the Task Handed to Capital Juries, 6 WIs. L. Rev. 1345 (1994). She stressed the need for personalized responsibility and individualized, contextualized decision making in sentencing determinations. Howarth contrasted the jury's fact-finding role in guilt trials, based on the traditional ethic of justice, with its moral role in penalty trials, based on an ethic of caring, compassion, and mercy. She found a hidden battleground of gender in capital juries— pitting rational versus irrational, active versus passive, thought versus feeling, objective versus subjective, abstract versus contextualized, distance versus connection, rules versus context, anger versus pity. Perhaps the most fundamental point is that there is simply no objective test, no rule to measure mitigation, no scale to quantify empathy-evoking evidence.

${ }^{35} 543$ U.S. 274 (2004).

${ }^{36}$ Id. at 285, quoting Eddings, supra note 22, at 114 . The Court also cited the relevance standard it had addressed directly in McKoy v. North Carolina, 494 U.S. 433, 440-441 (1990), where a state court dissent had been quoted with approval: "Relevant mitigating evidence is evidence which tends logically to prove or disprove some fact or circumstances which a fact-finder could reasonably deem to have mitigating value." Id. at 440 (quoting State v. McKoy, 372 S.E.2d 12, 45 [N.C. 1988]).

${ }^{37}$ Tennard, 543 U.S. at 287.

${ }^{38} 549$ U.S. 7 (2006).

${ }^{39} \mathrm{Id}$. at 21.

40554 U.S. 407 (2008).

${ }^{41} \mathrm{Id}$. at 420. Citations omitted.

${ }^{42}$ See Marla Sandys, Elizabeth S. Vartkessian, Heather Pruss, \& Sara M. Walsh, Chapter 4, "Setting the Stage and Listening to What Jurors Have to Tell Us about Mitigation" (drawing on their personal experience in Capital Jury Project research).
} 
Science Foundation. ${ }^{43}$ Over the next two decades, the CJP interviewed 1,198 jurors from 353 capital trials in fourteen states, using structured interviews of three to four hours in duration. Some fifty articles based on the CJP data have been published, along with books and doctoral dissertations completed and in progress. ${ }^{44}$ The interviews elicit both predetermined response options to structured questions and narrative accounts in jurors' own words in response to open-ended questions. These empirical findings have provided insights about the kinds of mitigating evidence that jurors have found effective, ${ }^{45}$ in the manner that is most effective, ${ }^{46}$ and at all stages of the trial (including voir dire and the guilt-innocence phase) because of the well-documented conclusion that nearly half the jurors believed they knew what the punishment should be before the sentencing phase of the trial began. ${ }^{47}$ In addition to the CJP's body of work, capital defense

\footnotetext{
${ }^{43}$ For a detailed description of the work of the Capital Jury Project, see http://www.albany.edu/scj/13189.php (last visited Jan. 25, 2017). See also William J. Bowers, The Capital Jury Project: Rationale, Design, and a Preview of Early Findings, 70 Indiana L.J. 1043 (1995).

${ }^{44}$ Most of these publications are available at http://www.albany.edu/scj/13194.php. (last visited Jan. 25, 2017). See also, for example, Scott E. Sundby, A Life and Death Decision: A Jury Weighs the Death Penalty (2005).
}

${ }^{45}$ See, e.g., Stephen P. Garvey, Aggravation and Mitigation in Capital Cases: What Do Jurors Think? 98 Columb. L. Rev. 1538 (1998) (finding mental illness and impairment highly mitigating, child abuse also carrying weight, and acceptance of responsibility highly mitigating); Scott E. Sundby, The Jury and Absolution: Trial Tactics, Remorse and the Death Penalty, 83 Cornell L. Rev. 1557 (1998) (finding that a denial defense is more likely to result in death sentence; without acceptance of responsibility, jurors are more cynical about child abuse and other mitigation); and Stephen P. Garvey, The Emotional Economy of Capital Sentencing, 75 N.Y.U. L. Rev. 26 (2000) (how empathy decreases likelihood jurors will vote for death, but sentencing process systematically distances jurors from defendants). Several articles have also examined what makes jurors choose death rather than life: John H. Blume, Sheri Lynn Johnson \& Scott E. Sundby, Competent Capital Representation: The Necessity of Knowing and Heeding What Jurors Tell Us about Mitigation, 36 Hofstra L. Rev. 1035 (2008); Ursula Bentele \& William J. Bowers, How Jurors Decide on Death: Guilt Is Overwhelming; Aggravation Requires Death; and Mitigation Is No Excuse, 66 Brook. L. Rev. 1013 (2002) (close to five out of ten jurors believed they must impose death penalty if crime is heinous, vile, or depraved; four out of ten if "future dangerousness" found); John H. Blume, Stephen P. Garvey, \& Sheri Lynn Johnson, Future Dangerousness in Capital Cases: Always “At Issue," 86 Cornell L. Rev. 397 (2001) (nearly 70 percent of jurors reported that preventing defendant from killing was important even though prosecution did not put future dangerousness "at issue"); William J. Bowers, Benjamin D. Fleury-Steiner, \& Michael E. Antonio, The Capital Sentencing Decision: Guided Discretion, Reasoned Moral Judgment, or Legal Fiction, Chapter 14 in America's Experiment with Capital Punishment: Reflections on the Past, Present, and Future of the Ultimate Penal SAnCtion (James R. Acker, Robert M. Bohm, \& Charles Lanier, eds., 2d ed. 2003) (effects of manner of the killing, legal misunderstanding of "presumption of death," and defendant's perceived demeanor); and Michael E. Antonio et al., Capital Jurors as the Litmus Test of Community: Conscience for the Juvenile Death Penalty, 87:6 JudiCATURE (May-June 2004) (defendant's courtroom demeanor key, including whether attorney(s) seemed to have close relationship with defendant).

${ }^{46}$ See Scott E. Sundby, The Jury as Critic: An Empirical Look at How Capital Juries Perceive Expert and Lay Testimony, 83 VA. L. Rev. 1109 (1997) (finding jurors did not like defense expert witnesses unless supported by contemporaneous information from lay witnesses; two-thirds of the witnesses jurors thought backfired were defense experts).

${ }^{47}$ See William J. Bowers, Marla Sandys, \& Benjamin D. Steiner, Foreclosed Impartiality in Capital Sentencing: Jurors' Predispositions, Attitudes and Premature Decision-Making, 83 CoRnell L. Rev. 1476 (1998) (interviews with 1,000 capital jurors in 11 states reveal that almost half believed they knew what punishment should be 
practice has been informed by the research of many other academics who have studied aspects of capital punishment. For example, social psychologist Craig Haney from the University of California, Santa Cruz, has published widely on research related to mitigation. ${ }^{48}$ Sociologist Michael L. Radelet from the University of Colorado, a prolific author on race effects, deterrence, wrongful convictions, and other issues, has long maintained a chronological inventory of every nonstatutory mitigating factor ever found in Florida death penalty cases. ${ }^{49}$

\section{Prevailing Norms for the Investigation and Presentation of Mitigating Evidence}

On five separate occasions in recent years, the Supreme Court has assessed-and found wanting - trial counsel's failure to investigate, develop, and present available mitigation evidence: Williams v. Taylor, ${ }^{50}$ Wiggins v. Smith, ${ }^{51}$ Rompilla v. Beard, ${ }^{52}$ Porter v. McCollum, ${ }^{53}$ and Sears v. Upton. ${ }^{54}$ Every case but Sears was tried in the 1980 s, and Sears was tried in 1993. In Williams, the Court reaffirmed an all-encompassing view of mitigation and found trial counsel ineffective for failing to prepare the mitigation case until a week before trial in 1986 and failing to conduct an investigation of the readily available mitigating evidence (nightmarish childhood, borderline retardation, model prisoner status, etc.). In Wiggins, a case tried in 1989, trial counsel were found deficient in their

before sentencing phase of trial began); William J. Bowers, The Capital Jury Project, supra note 43 (a "good many" of the jurors were "absolutely convinced" of the appropriate punishment-usually death—before the sentencing phase even began); Wanda D. Foglia, They Know Not What They Do: Unguided and Misguided Decision-Making in Pennsylvania Capital Cases, 20(1) Justice Quarterly 187 (2003) (interviews with 916 jurors from 257 trials in 11 states found that 48.3 percent said they had decided what the punishment should be before the sentencing phase had begun, and of those who chose death early, 75 percent never wavered from initial choice); and Bowers, Fleury-Steiner, \& Antonio (2003), supra note 45 (most jurors reported discussing punishment during guilt phase; the earlier the punishment decision is made, the more likely it is for death). This research has led to the well-established capital defense practice of "frontloading" mitigating evidence during voir dire and the guilt-innocence phase of the trial. See infra note 115.

${ }^{48}$ See, e.g., Haney's book, Death by Design: Capital Punishment as a Social Psychological System (2005). His influential articles include The Social Context of Capital Murder, supra note 9; Violence and the Capital Jury: Mechanisms of Moral Disengagement and the Impulse to Condemn to Death, 49 STANFord L. Rev. 1447 (1997); Condemning the Other in Death Penalty Trials: Biographical Racism, Structural Mitigation, and the Empathic Divide, 53 DePaul L. Rev. 1557 (2004); Evolving Standards of Decency: Advancing the Nature and Logic of Capital Mitigation, 36 Hofstra L. Rev. 835 (2008); Media Criminology and the Death Penalty, supra note 9; and On Mitigation as Counter-Narrative: A Case Study of the Hidden Context of Prison Violence, supra note 9.

${ }^{49}$ The list of nonstatutory mitigating factors ran to 265 pages when last updated (August 16, 2015), http:// www.colorado.edu/sociology/sites/default/files/attached-files/florida_death_cases_where_non-statutory_miti gators_were_found.pdf (last visited Jan. 25, 2017).

50529 U.S. 362 (2000).

51539 U.S. 510 (2003).

52545 U.S. 374 (2005).

53558 U.S. 30 (2009) (per curiam).

${ }^{54} 561$ U.S. 945 (2010) (per curiam). 
performance, despite having had their client examined by one mental health expert, because they failed to conduct a complete social history investigation in accordance with the ABA Guidelines for the Appointment and Performance of Defense Counsel in Death Penalty Cases (ABA Guidelines). "Despite these well-defined norms, however, counsel abandoned their investigation of petitioner's background after having acquired only rudimentary knowledge of his history from a narrow set of sources." ${ }^{55}$ In Rompilla, tried in 1988, counsel were found deficient "even when a capital defendant's family members and the defendant himself have suggested that no mitigating evidence is available" and despite consulting three mental health experts. ${ }^{56}$ Similarly, in Porter, also tried in 1988, counsel were found deficient despite a "fatalistic and uncooperative" client because "that does not obviate the need for defense counsel" to conduct mitigation investigation. ${ }^{57}$ Quoting Williams, the Court in Porter reaffirmed this duty: "It is unquestioned that under the prevailing professional norms at the time of Porter's trial, counsel had an 'obligation to conduct a thorough investigation of the defendant's background." 58 Among the mitigation that Porter's counsel failed to present was "brain damage that could manifest in impulsive, violent behavior." ${ }^{\text {"I }}$ In Sears, the Court found trial counsel ineffective in a 1993 trial even though they had presented seven witnesses in the penalty proceedings. The Court noted, "We have never limited the prejudice inquiry under Strickland to cases in which there was only 'little or no mitigation evidence' presented. . . ." 60 Postconviction evidence emphasized significant frontal lobe brain damage that caused deficiencies in cognitive functioning and reasoning. ${ }^{61}$ Four of these five individuals have subsequently received sentences of less than death, and the fifth case is pending as of this writing. Terry Williams received a life sentence by negotiated disposition in Danville, Virginia, in 2000. ${ }^{62}$ On October 15, 2004, the State of Maryland agreed to a disposition sending Kevin Wiggins to a state facility for mental health treatment and rehabilitation services but making him eligible for parole immediately based on time already served. ${ }^{63}$ On August 13, 2007, the Lehigh County (Pennsylvania) District Attorney's Office stipulated to a life sentence for Ronald Rompilla. ${ }^{64}$ On July 21, 2010, the Brevard-Seminole (Florida) State Attorney's Office announced that it would allow George Porter Jr. to be

\footnotetext{
${ }^{55}$ Wiggins, 539 U.S. at 524.

${ }^{56}$ Rompilla, 545 U.S. at $377,379$.

${ }^{57}$ Porter, 558 U.S. at 40.

${ }^{58}$ Id. at 39 (citation omitted).

${ }^{59} \mathrm{Id}$. at 36 .

60561 U.S. at 954 .

${ }^{61} \mathrm{Id}$. at 946.

${ }^{62}$ See Frank Green, Death Penalty Cases Scrutinized: More Hearings Are Being Ordered in Virginia, Richmond Times-Dispatch (Apr. 9, 2001) at A1, truthinjustice.org/va-dpreview.htm.

${ }^{63}$ See Jenner \& Block, 12 Year Battle for Kevin Wiggins Comes to an End (Oct. 15, 2004), https://jenner.com/ library/news/7810.

${ }^{64}$ See Associated Press, Death Row Inmate Gets New Life Term, USA Today (Aug. 13, 2007), usatoday.com/ news/topstories/2007-08-13-477084247_x.htm.
} 
resentenced to life. ${ }^{65}$ All five cases involved mental health evidence that was not discovered and presented at trial.

Not only do these cases make clear counsel's obligation to conduct thorough mitigation investigation, they also dispose of some convenient excuses offered by defense teams for the failure to do so. Blame the client? Rompilla and Porter involved uncooperative and uninterested clients, but that did not prevent the Court from finding trial counsel's mitigation presentation to be both incompetent and prejudicial. ${ }^{66}$ The mitigation was "double-edged"? Williams and Porter explained that mitigation investigation inevitably uncovers the good and the bad, but counsel's job is to integrate seemingly harmful behaviors into a narrative that evokes empathy. ${ }^{67}$ Child abuse is irrelevant to adult behavior? Although Mr. Porter was fifty-four years old at the time of the capital crimes, the Supreme Court noted that his childhood experience could not be discounted to irrelevance but rather was an important part of the overall mitigation package. $^{68}$

In a noncapital case dealing with the collateral immigration consequences of criminal defense representation, Padilla v. Kentucky, ${ }^{69}$ Justice Stevens outlined a template for identifying the objective indicia of prevailing professional norms: "We long have recognized that 'prevailing norms of practice as reflected in American Bar Association standards and the like . . . are guides to determining what is reasonable. . . ."70 Justice Stevens cited Strickland v. Washington, ${ }^{71}$ Bobby v. Van Hook, ${ }^{72}$ Florida v. Nixon, ${ }^{73}$ Wiggins v. Smith, ${ }^{74}$ and Williams v. Taylor. ${ }^{75}$ Justice Stevens concluded: "Although they are 'only guides,' Strickland, ${ }^{76}$ and not 'inexorable commands,' Bobby, ${ }^{77}$ these standards may be

\footnotetext{
${ }^{65}$ Kaustuv Basu, Aging Killer May Get Reprieve from Death Row, FLA. Today (July 21, 2010).

${ }^{66}$ See Rompilla, 545 U.S. at 381 (client "bored being here listening" to discussion of mitigation strategy; at times "actively obstructive by sending counsel off on false leads"); Porter, 558 U.S. at 40 ("fatalistic or uncooperative" client does not obviate the need for mitigation investigation).

${ }^{67}$ See Williams, 529 U.S. at 396 ("Of course, not all of the additional evidence was favorable to Williams"), 418 (murder "just one act in a crime spree that lasted most of Williams's life"); Porter, 558 U.S. at 43-44 ("the relevance of Porter's extensive combat experience is not only that he served honorably under extreme hardship and gruesome conditions, but also that the jury might find mitigating the intense stress and mental and emotional toll that combat took on Porter. The evidence that he was AWOL is consistent with this theory of mitigation and does not impeach or diminish the evidence of this service"). The blemishes in Mr. Porter's military record - his absences without leave-were best understood as part of his struggle to regain normalcy after his horrific combat exposure in Korea.

${ }^{68}$ See Porter, 558 U.S. at 37, 43.

${ }^{69} 559$ U.S. 356,366 (2010).

${ }^{70} \mathrm{Id}$. at 366 .

${ }^{71} 466$ U.S. 668, 688 (1984).

${ }^{72} 558$ U.S. 4 (2009) (per curiam).

${ }^{73} 543$ U.S. 175, 191, and n.6 (2004).

${ }^{74} 539$ U.S. 510,524 (2003).

${ }^{75} 529$ U.S 362, 396 (2000).

${ }^{76} 466$ U.S. at 688.

77558 U.S. at 8.
} 
valuable measures of the prevailing norms of effective representation. . . ."78 Justice Stevens also cited law review articles and the publications of criminal defense and public defender organizations (such as the National Association of Criminal Defense Lawyers and the National Legal Aid and Defender Association) as guides to prevailing professional norms. ${ }^{79}$ In a capital case, the High Court endorsed Justice Stevens's analysis of "prevailing professional norms," Padilla, 559 U.S. at 366, quoting his first two sentences verbatim. ${ }^{80}$

The ABA Guidelines, first published by the American Bar Association in 1989, have since evolved to reflect the norms of the capital defense bar in relation to the investigation and presentation of mitigation evidence. ${ }^{81}$ The guidelines were adopted from Standards for the Appointment of Defense Counsel in Death Penalty Cases published by the National Legal Aid and Defender Association in $1985 .{ }^{82}$ In the first edition of the $A B A$ Guidelines, each black-letter guideline was explained by a commentary, with reference to supporting authorities (such as law review articles and capital trial manuals from multiple jurisdictions, including California, Indiana, Kentucky, Ohio, and Tennessee) ${ }^{83}$ Fourteen years later, the $A B A$ Guidelines were revised to reflect continuing advances in capital defense practice. ${ }^{84}$ Most notably, the 2003 revision recognizes that the minimal capital defense team should consist of two lawyers, a fact investigator, and a mitigation specialist, as well as someone (one of these four or an additional person) qualified by training and experience to screen for mental or psychological disorders or impairments. ${ }^{85}$ The more extensive commentary accompanying the 2003 revision contains 357 footnotes, including some eighty footnotes to law review articles by academics with capital defense experience, numerous additional references to defense bar publications (such as The Champion, published by the National Association of Criminal Defense Lawyers, and Indigent Defense, published by the National Legal Aid and Defender Association), and citations to multiple trial manuals. ${ }^{86}$

\footnotetext{
${ }^{78}$ Padilla, 559 U.S. at 367.

${ }^{79} \mathrm{Id}$. at 367.

${ }^{80}$ Hinton v. Alabama, 134 S. Ct. 1081, 1088 (2014) (per curiam).

${ }^{81}$ See Russell Stetler \& Aurélie Tabuteau, The ABA Guidelines: A Historical Perspective, 43 Hofstra L. Rev. 731

(2015) (noting how the ABA Guidelines reflect "the strategies, experiential expertise, and collective wisdom of the public defenders, court-appointed panel lawyers, low-salaried lawyers from nonprofits, and pro bono volunteers who have represented capital defendants successfully"). See also Russell Stetler \& W. Bradley Wendel, The ABA Guidelines and the Norms of Capital Defense Representation, 41 Hofstra L. Rev. 635 (2013) (norms reflect what counsel ought to do; mere quantity of experience does not make someone qualified).

${ }^{82}$ Stetler \& Tabuteau, ABA Guidelines, supra note 81 , at 741 .

${ }^{83} \mathrm{Id}$. at 742 .

${ }^{84} I d$. at 743 .

${ }^{85}$ See Guideline 4.1.A.1-2, The Defense Team and Supporting Services, in ABA Guidelines (rev. 2003), published in 31 Hofstra L. Rev. 913, 952 (2003).

${ }^{86}$ See Stetler \& Tabuteau, ABA Guidelines, supra note 81, at 743, 745-46.
} 
Guideline 10.7, Investigation, stresses counsel's obligation "to conduct thorough and independent investigations relating to the issues of both guilt and penalty." ${ }^{87}$ The guiltinnocence investigation "should be conducted regardless of any admission or statement by the client concerning the facts of the alleged crime, or overwhelming evidence of guilt, or any statement by the client that evidence bearing upon guilt is not to be collected or presented." ${ }^{8}$ The mitigation investigation "should be conducted regardless of any statement by the client that evidence bearing upon penalty is not to be collected or presented." ${ }^{99}$ The twelve-page commentary to this section discusses mitigation at length and advises bluntly:

The duty to investigate exists regardless of the expressed desires of the client. Nor may counsel "sit idly by, thinking that investigation would be futile." Counsel cannot responsibly advise a client about the merits of different courses of action, the client cannot make informed decisions, and counsel cannot be sure of the client's competency to make such decisions, unless counsel has first conducted a thorough investigation with respect to both phases of the case. ${ }^{90}$

The commentary notes that "penalty phase preparation requires extensive and generally unparalleled investigation into personal and family history" and outlines half a dozen areas of specific mitigation inquiry (medical history, family and social history, educational history, military service, employment and training history, and prior juvenile and adult correctional experience)."11 The mitigation investigation "should begin as quickly as possible" because it will also affect first-phase defenses, motion practice, plea negotiations, and so on. ${ }^{22}$ The mitigation investigation always has two tracks: interviewing witnesses (requiring the skills to overcome barriers to disclosure of sensitive information) and gathering records. ${ }^{93}$ The commentary continues, "Records should be requested concerning not only the client, but also his parents, grandparents, siblings, cousins, and children. A multi-generational investigation extending as far as possible vertically and horizontally frequently discloses significant patterns of family dysfunction and may help establish or strengthen a diagnosis or underscore the hereditary nature of a particular impairment." ${ }^{4}$

Guideline 10.5, Relationship with the Client, also includes extensive commentary about the high "prevalence of mental illness and impaired reasoning" in the capital client

\footnotetext{
${ }^{87} 31$ Hofstra L. Rev. at 1015, 10.7.A.

${ }^{88}$ Id. Guideline 10.7.A.1.

${ }^{89} \mathrm{Id}$. Guideline 10.7.A.2.

${ }^{90} \mathrm{Id}$. at 1021 (citations omitted).

${ }^{91} \mathrm{Id}$. at $1022-23$ (citation omitted).

${ }^{92} \mathrm{Id}$. at 1023.

${ }^{93} \mathrm{Id}$. at 1024 .

${ }^{94} I d$. at $1024-25$ (citations omitted).
} 
population so that "it must be assumed that the client is emotionally and intellectually impaired." 95 The commentary warns that it is "ineffective assistance for counsel to simply acquiesce" if the client does not want to present mitigation. ${ }^{96}$

The year of the ABA Guidelines revision, 2003, was coincidentally the year in which the High Court in Wiggins acknowledged the role of the nonlawyer who had gathered the mitigating evidence to establish prejudice in the successful ineffective assistance claim. ${ }^{97}$ It was time to summarize in more detail the performance standards of the mitigation function of defense teams in capital cases. Professor Sean D. O'Brien of the University of Missouri-Kansas City School of Law led a four-year effort to develop specific guidelines in this area. ${ }^{98} \mathrm{He}$ describes how drafts were circulated at more than ten national capital defense training programs before the final text was published in 2008 in Hofstra Law Review. ${ }^{99}$

The organizational scheme of the "Supplementary Guidelines for the Mitigation Function of Defense Teams in Death Penalty Cases" 100 follows that of the ABA black-letter guidelines. The introductory section makes clear that ultimate responsibility for the multifaceted and multidisciplinary mitigation investigation rests with counsel. ${ }^{101}$ Supplementary Guideline 4.1 discusses the role of the mitigation specialist (defined as an agent of capital defense counsel) but stresses counsel's duty to select a competent team, enforce high-quality performance, and educate the team about applicable law. ${ }^{102}$ Supplementary Guideline 5.1 discusses the needed skill sets, including cultural competency, knowledge of mental health signs and symptoms, and skills in interviewing and record gathering. ${ }^{103}$ The importance of multigenerational evidence is emphasized (Supplementary Guideline 10.11.B), along with the need for multiple, in-person, face-to-face, one-on-one interviews with all relevant witnesses (Supplementary Guideline 10.11.C). ${ }^{104}$

Supplementary Guideline 5.1.B specifies the need for someone with

the training and ability to obtain, understand and analyze all documentary and anecdotal information relevant to the client's life history. Life history includes, but is not limited to: medical history; complete prenatal, pediatric and adult health information; exposure to harmful substances in utero and in the environment; substance

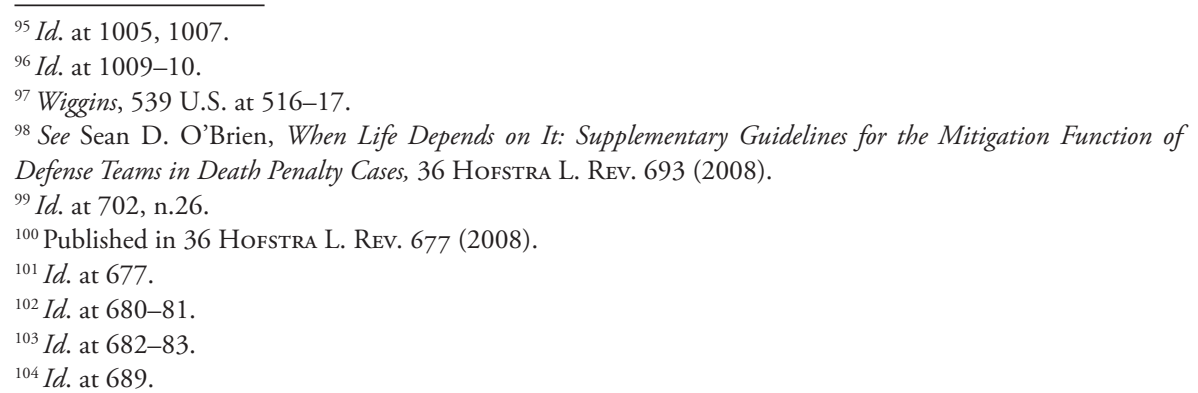


abuse history; mental health history; history of maltreatment and neglect; trauma history; educational history; employment and training history; military experience; multi-generational family history, genetic disorders and vulnerabilities, as well as multi-generational patterns of behavior; prior adult and juvenile correctional experience; religious, gender, sexual orientation, ethnic, racial, cultural and community influences; socio-economic, historical, and political factors. ${ }^{105}$

Supplementary Guideline 5.1.C continues:

Mitigation specialists must be able to identify, locate and interview relevant persons in a culturally competent manner that produces confidential, relevant and reliable information. They must be skilled interviewers who can recognize and elicit information about mental health signs and symptoms, both prodromal and acute, that may manifest over the client's lifetime. They must be able to establish rapport with witnesses, the client, the client's family and significant others that will be sufficient to overcome barriers those individuals may have against the disclosure of sensitive information and to assist the client with the emotional impact of such disclosures. They must have the ability to advise counsel on appropriate mental health and other expert assistance. ${ }^{106}$

A core team member, usually the mitigation specialist, must also have the specialized training, as described in Supplementary Guideline 5.1.E, to identify, document, and interpret

symptoms of mental and behavioral impairment, including cognitive deficits, mental illness, developmental disability, neurological deficits; long-term consequences of deprivation, neglect and maltreatment during developmental years; social, cultural, historical, political, religious, racial, environmental and ethnic influences on behavior; effects of substance abuse and the presence, severity and consequences of exposure to trauma. ${ }^{107}$

Because the mitigation function continues to evolve, neither the $A B A$ Guidelines nor the Supplementary Guidelines for the Mitigation Function can constitute the last word on the subject. However, they continue to represent the best summaries of performance standards in this crucial area of capital defense practice, and they remain the appropriate primary sources for defense teams to consult when confronting any questions about the development of mitigation evidence.

\footnotetext{
${ }^{105} \mathrm{Id}$. at 682 .

${ }^{106} I d$.

${ }^{107} I d$. at 683.
} 


\section{Mitigation in Current Capital Practice}

Death sentences and executions have become extremely rare ${ }^{108}$ thanks in large part to effective mitigation investigation and presentation. Several states have replaced random systems of court-appointed counsel with specialized institutional capital defenders that employ in-house mitigation staff, resulting in dramatic decreases in the number of death sentences. Virginia, for example, established four regional capital defender offices in 2004 and sent only six people to death row in the nine years from 2007 to 2015 compared to forty over the previous eight years. ${ }^{109}$ An analysis by the North Carolina Office of Indigent Defense Services of all potentially capital cases with warrant dates after July 1 , 2001, found that only 3 percent of "proceeded capital cases" (where the prosecution pursued the death penalty at some point) ended in a death verdict. ${ }^{110}$ The South Carolina Commission on Indigent Defense opened a Capital Trial Division in September 2008. According to data compiled by that office, forty-four death penalty cases (trials, retrials, or resentencings) were closed between September 2008 and October 16, 2012, resulting in six death sentences imposed by a jury and one by a judge (i.e., about 16 percent of authorized cases). ${ }^{111}$ Data on federal capital defendants, from 1989 to 2009, identified 2,975 federal capital defendants who were eligible for the death penalty, with 262 authorized defendants who had been tried, 68 of whom received death sentences. ${ }^{112}$ Three-quarters of the defendants in authorized cases avoided the death penalty, and a scant 2 percent of the death-eligible federal defendants received the death penalty. ${ }^{113}$

But, while the number of new death sentences has dwindled, individuals are still sentenced to death. And — as has been true for the last forty years — the death penalty is not

\footnotetext{
${ }^{108}$ See Miller v. Alabama, 132 S. Ct. 2455, 2468, n.7 (2012) ("Although adults are subject ... to the death penalty in many jurisdictions, very few offenders actually receive that sentence. See, e.g., Dept. of Justice, Bureau of Justice Statistics, S. Rosenmerkel, M. Durose, \& D. Farole, Felony Sentences in State Courts 2006-Statistical Tables, p. 28 [Table 4.4] [rev. Nov. 22, 2010]").

${ }^{109}$ Larry O’Dell, Pace of Death Sentences, Executions Slows in Virginia, Associated Press (May 3, 2015), http:// www.legalnews.com/detroit/1405666.

${ }^{110}$ North Carolina Office of Indigent Defense Services, FY07 Capital Trial Case Study, December 2008 (date included cases disposed of by April 22, 2008). http://www.ncids.org/Reports\%20\&\%20Data/Latest $\% 20$ Releases/FY07CapitalStudyFinal.pdf.

${ }^{111}$ Spreadsheet provided to the authors by the South Carolina Commission on Indigent Defense Capital Trial Division. That office represented twenty-four of the forty-four defendants, only one of whom received a death sentence.

${ }^{112}$ Jon B. Gould \& Lisa Greenman, Report to the Committee on Defender Services, Judicial Conference of the United States, Update on the Cost and Quality of Defense Representation in Federal Death Penalty Cases (September 2010) at 8-10, http://uscourts.gov/FederalCourts/Appointment OfCounsel/Publications/UpdateFederalDeathPenaltyCases.aspx.

${ }^{113}$ See also Stetler \& Wendel, Norms of Capital Representations, supra note 81, at 684-95 (summarizing rarity of death sentences in data from New York [1995-2004], California [1977-89], Connecticut [1973-2007], Georgia [1995-2004], Kentucky [1976-86], Indiana [1990-2000], Missouri [1990-2006], Nebraska [1973-99], Colorado [1980-99], New Mexico [1979-2007], Maryland [1978-99], Delaware [dates unspecified], and the U.S. military [1984-2005]).
} 
necessarily imposed in the "worst" cases. Rather, it is often the product of an inadequate mitigation investigation and presentation. As we mentioned earlier in this chapter, in the more recent death cases, the outcomes were not (necessarily) due to the defense team's failure to investigate mitigation evidence. Instead, what we too often see is a defense team that either failed to dig deeply enough and/or failed to integrate the evidence they did discover into a persuasive and credible life narrative. The ways in which counsel fail on this score are too detailed a subject to do justice to in this chapter, so we discuss only those we find most common.

The first is the failure to develop an integrated, coherent theory of the case that resonates at both the guilt-or-innocence phase and the penalty phase of the trial. The most extreme example is when the defense team maintains the client is not guilty (as in "wrong person/didn't do it") at the guilt-or-innocence phase and then-following conviction-presents at the penalty phase some form of "traditional mitigation" (e.g., brain damage, mental illness, substance abuse) as a reason not to impose the death penalty. Both the empirical evidence ${ }^{114}$ and our experience make clear that in such cases juries are likely to reject the mitigation evidence as just another attempt by defendants to avoid responsibility for their actions. To jurors, the common reaction is that "those lawyers tried to fool us at the first phase by denying their client's guilt, and now they are trying to trick us into giving the defendant life." It is therefore imperative that the mitigation case-whatever it turns out to be after the robust investigation needed to determine what the client's life story is - be integrated into and consistent with the defense's theory of the crime. ${ }^{115}$ Doing so also, in many cases, provides opportunities to "frontload" the mitigation by making it part of the first phase of the trial. Presenting mitigation during the guilt-or-innocence phase is often critical because we know that many jurors make the life-or-death decision during this phase. ${ }^{116}$

\footnotetext{
${ }^{114}$ Blume, Johnson, \& Sundby, Competent Capital Representation, supra note 45, 36 Hofstra L. Rev. at $1044-$ 45. See also supra note 47.

${ }^{115} \mathrm{~A}$ similar defect in some mitigation cases is the failure to develop a nexus between the mitigation and the offense. While it is true that legally no such nexus is required for mitigation evidence to be relevant and admissible (see supra notes 35-37), the reality is that evidence in mitigation is most persuasive when it helps explain, or at least contextualize, the offense. If a total disconnect exists between the mitigation and the offense, jurors are much more likely to reject the mitigation evidence, often with a rationalization such as "I was abused too, but I didn't go out and kill anyone."

${ }^{116}$ Blume, Johnson, \& Sundby, Competent Capital Representation, supra note 45, 36 Hofstra L. Rev. at 1043; see also Ursula Bentele \& William J. Bowers, How Jurors Decide Death, supra note 45, 66 Brook. L. Rev. 1011, 1053-55 (2001). An excellent example of frontloading occurred in the South Carolina capital trial of Susan Smith, who was charged with the murder of her two children. The prosecution presented evidence that Smith killed her children so that she could marry a wealthy young businessman with whom she was sexually involved. To rebut the State's motive evidence, the defense called a mental health expert who described Smith's history of sexual abuse, depression, and suicide attempts and who further opined that Smith actually intended to kill herself and her children while suffering a major depressive episode. Smith was found guilty, but after brief deliberations at penalty, the jury returned a unanimous life verdict. Associated Press, Life Term Given Mother Who Drowned 2 Sons, L.A. Times, July 30, 1995, at A6.
} 
The second way in which mitigation cases can ring hollow is when the defense team relies too heavily on mental health experts who were retained postoffense to make the case for life. The cornerstone of any mitigation case is a detailed, exhaustive social history investigation conducted by a trained mitigation specialist. ${ }^{117}$ In most cases, the social history investigation should be conducted before any experts are retained because the results will dictate the type of experts needed and the referral questions they will address. ${ }^{118}$ At trial, however, jurors often have negative reactions to defense expert witnesses, especially those retained after the crime. Jurors tend to view such experts as "hired guns" who will say what they are paid to say. Such expert witnesses are most persuasive in telling the story for life when they are an "accompanist" as opposed to a "soloist." 119 More specifically, the defense team must integrate experts with lay witnesses and supporting social history records. Experts are most persuasive when adding context to facts and details of the client's life history presented by others; relying exclusively on such experts to make the case for life is a recipe for death. ${ }^{120}$ It is also helpful to bolster the testimony of retained experts by using the testimony of experts who were not retained, such as psychologists who had previously treated the defendant or teachers who had witnessed the defendant's academic struggles. ${ }^{121}$

\footnotetext{
${ }^{117}$ John H. Blume, Mental Health Issues in Criminal Cases, The Elements of a Competent and Reliable Mental Health Evaluation, Mental Health Experts Manual, Chapter 5 (Kentucky Dept. of Public Advocacy, 8th ed. 2005); John H. Blume and Pamela B. Leonard, Principles of Developing Mental Health Issues in Criminal Cases, id., Chapter 6 . This investigation must be multigenerational and involves interviewing the client's family, friends, coaches, teachers, treating physicians, jailers, correctional officers, among others, and gathering all available social history records, including school records, employment records, family medical records, social security records, military records, prison records, and so on. In short, the client's life must be examined from a variety of perspectives with the benefit of multiple sources. See also Richard G. Dudley Jr., \& Pamela Blume Leonard, Getting It Right: Life History Investigation as the Foundation for a Reliable Mental Health Assessment, 36 Hofstra L. Rev. 963 (2008); Russell Stetler, Mental Health Evidence and the Capital Defense Function: Prevailing Norms, 82 UMKC L. Rev. 407 (2014).

${ }^{118}$ The exception to this general rule is when the client is psychotic or has some other acute mental health issue requiring treatment.

${ }^{119}$ Scott E. Sundby, The Jury as Critic, supra note 46, 83 VA. L. Rev. at 1123-26.

${ }^{120}$ Blume, Johnson, \& Sundby, Competent Capital Representation, supra note 45, 36 Hofstra L. Rev. at 1062.

${ }^{121} I d$. During the operative years of the New York death penalty statute (1995 to 2004), for example, the Capital Defender Office offered the testimony of historical experts in several cases. A school psychologist who had tested a client routinely as part of mandated triennial review for special education explained the significance of his borderline intellectual functioning (FS IQ 76-81). People v. George Davis Bell (Ind. 128-97, Judge Cooperman, Queens County, N.Y., 1999). In another case, a different school psychologist explained the impact of learning disabilities (at age 11, reading just above a second-grade level; at 14, just above fourth grade; and at 17, just above fifth grade). People v. José J. Santiago (Ind. 1210/99, Judge Bristol, Monroe County, N.Y., 2000). In a third case, a psychiatrist had treated the client's mother after her suicide attempt when the client was nine- thirty years before the capital trial. From the records, the psychiatrist testified to the history of mood disorders and suicidality in the maternal lineage, as well as family dysfunction, including fights over promiscuity, gambling, and drinking. From her current perspective, the psychiatrist opined about the devastating impact on the children of the mother's mood disorder, suicidality, and psychiatric removal from the family. People v. John F. Owen (Ind. 547-99 cons. with 414-99, Judge Egan, Monroe County, N.Y., 2001). See Russell
} 
Finally, death sentences are sometimes imposed because the defense team fails to create empathy for the client, instead making the client seem damaged beyond redemption, hope, and mercy and therefore not worth saving. This trap is easy to fall into given that many of our clients have endured horrific abuse that has left them extremely impaired, or they are severely mentally ill or cognitively limited. But all of our clients are also more than the sum of mitigating circumstances, and jurors choose life when the defendant is shown to be likeable, when the defendant's story elicits empathy from the jurors, and when jurors can imagine themselves in the defendant's position. Thus, in addition to detailing a client's suffering and impairments, it is also important to humanize the client as an individual with relationships, friends, emotions, and possibilities.

\section{The Future of Mitigation}

In Atkins v. Virginia ${ }^{122}$ and Roper v. Simmons, ${ }^{123}$ the Court converted two common areas of mitigation (intellectual disability and youth) into categorical bars exempting from execution persons with intellectual disability and those who were under the age of eighteen at the time of the capital crime. The Court recognized that persons with intellectual disability (then known as "mental retardation") had disabilities in reasoning, judgment, and impulse control. ${ }^{124}$ Juveniles had an underdeveloped sense of responsibility, a vulnerability to negative influences, and a lack of true depravity. ${ }^{125}$ Part of the Court's justification for these categorical exemptions was the lesser culpability of these individuals compared to adult offenders with higher cognitive functioning, and the Court further acknowledged that individuals in both categories were at a heightened risk of "wrongful execution" because of an increased likelihood of confessing falsely, as well as impairments in communication with counsel, testifying in their own defense, and expressing remorse. $^{126}$

Many observers quickly noted, however, that these same characteristics apply to individuals over the age of eighteen who did not meet the strict criteria for intellectual disability (significantly subaverage general intellectual functioning accompanied by deficits in adaptive functioning and developmental onset prior to age eighteen), ${ }^{127}$ but who suffer from other disabling conditions such as schizophrenia, autism spectrum disorders,

\footnotetext{
Stetler, The Mystery of Mitigation: What Jurors Need to Make a Reasoned Moral Response in Capital Sentencing, 11 U. PA. J. L. \& Soc. Change 237, 258 (n.92) (2007-08).

122536 U.S. 304 (2002).

123543 U.S. 551 (2005).

${ }^{124}$ Atkins, 536 U.S. at 306.

${ }^{125}$ Roper, 543 U.S. at 569-570, 573.

${ }^{126}$ Roper, 543 U.S. at 573 (unacceptable likelihood that brutality of crime would overpower mitigating arguments); Atkins, 536 U.S. at 306-07 (impairments can jeopardize reliability and fairness of capital proceedings). ${ }^{127}$ See American Psychiatric Association, Diagnostic and Statistical Manual of Mental Disorders, 4th ed., text revision (“DSM-IV-TR”) 41 (2000).
} 
or fetal alcohol spectrum disorders. A task force of the American Bar Association, American Psychiatric Association, American Psychological Association, and National Alliance on Mental Illness made a series of recommendations to create additional categorical exemptions for people whose intellectual disability resulted from dementia or traumatic brain injury subsequent to the developmental years; people with a severe mental disorder or disability impairing their ability to appreciate wrongfulness, exercise rational judgment in relation to conduct, or conform to the requirements of law; and people whose mental disorders manifested after sentencing but who could not make rational decisions about forgoing or terminating postconviction proceedings, or could not assist counsel, or could not understand the nature of the punishment or the reason for its imposition in the prisoner's own case. ${ }^{128}$ Some litigators attempted to "extend Atkins" by showing how individual clients shared the specific disabilities that had led the Court to exempt people who met the well-defined criteria for intellectual disability.

One of our colleagues, Mark E. Olive from the Habeas Assistance and Training Counsel Project, suggested a different approach. Instead of attempting to define additional narrow categories of exemption that courts might recognize, Olive suggested that the High Court had simply recognized the exempted categories as subsets of the much broader population of "average murderers" who do not meet the Court's own criteria reserving capital punishment for the most aggravated crimes and the most culpable individuals. $^{129}$

Meanwhile, as Professor Scott E. Sundby points out, the Court has recognized that "even though intellectual disability and youth were powerful mitigators, jurors were not able to reliably use them in their decision making." 130 Sundby suggests the Court has been motivated by an "unreliability principle": "If too great a risk exists that constitutionally protected mitigation cannot be reliably assessed, the unreliability means that that death penalty cannot be constitutionally imposed." ${ }^{131}$ He identified six factors likely to lead to unreliable outcomes: (1) the defendant's impaired ability to cooperate with counsel (thus affecting counsel's ability to prepare), ${ }^{132}$ (2) the defendant's impaired ability to be a witness in his or her own defense, ${ }^{133}$ (3) the defendant's distorted decision

\footnotetext{
${ }^{128}$ Published in 30 Mental \& Physical Disability L. Rep. 668 (Sept.-Oct.2006).

${ }^{129}$ See Atkins, 536 U.S. at 319: "Since Gregg, our jurisprudence has consistently confined the imposition of the death penalty to a narrow category of the most serious crimes. For example, in Godfrey v. Georgia, we set aside a death sentence because the petitioner's crimes did not reflect 'a consciousness materially more "depraved" than that of any person guilty of murder.' If the culpability of the average murderer is insufficient to justify the most extreme sanction available to the State, the lesser culpability of the mentally retarded offender surely does not merit that form of retribution." (Citations omitted; emphasis added.) See also Kennedy v. Louisiana, supra notes, and text accompanying notes, 40-41.

${ }^{130}$ Scott E. Sundby, The True Legacy of Atkins and Roper: The Unreliability Principle, Mentally Ill Defendants, and the Death Penalty's Unraveling, 23 WM. \& MARY BiLl RTs. J. 487 (2014).

${ }^{131}$ Id.

${ }^{132} \mathrm{Id}$. at 512-14.

${ }^{133} \mathrm{Id}$. at 515 .
} 
making, ${ }^{134}$ (4) the jurors' view of these disabilities as a two-edged sword, ${ }^{135}$ (5) scientific uncertainty (because science is always advancing and discarding previous received wisdom), ${ }^{136}$ and (6) the risk that jurors will find that the brutality of the crimes overwhelms the mitigating condition. ${ }^{137}$

Professor Robert J. Smith argues that the death penalty is imposed with regularity upon offenders with "insufficient personal culpability" as a result of "major functional impairments - severe mental illness, intellectual deficiencies, and other serious cognitive and behavioral deficits." ${ }^{138} \mathrm{He}$ found that "most of the last hundred people executed in America suffered from the aftermath of complex trauma, endured a serious mental illness, or had a significant intellectual impairment. Some were not even old enough to buy a beer." 139 Smith argues that there are no metrics "that are as easy to apply as chronological age or IQ scores" to measure functional impairments, so the reliability of jury verdicts is undermined. ${ }^{140} \mathrm{He}$ challenges "the core conceptualization of the typical death-eligible murderer as pitiless and cold-blooded." ${ }^{141} \mathrm{He}$ further argues that the problem of insufficient culpability could ultimately spell the end of capital punishment in the United States because "when lawyers fail to conduct adequate mitigation investigation, jurors are unable to perform their moral and legal function of deciding which offenders are truly among the most culpable offenders." 142 Noting the "increased professionalization" of the mitigation function, with increased hiring of mitigation staff in institutional offices and "increased training opportunities for mitigation specialists nationwide," Smith acknowledges the importance of the "Supplementary Guidelines for the Mitigation Function" in establishing high standards in this area of capital defense. ${ }^{143}$ He concludes by challenging the "myth of extreme culpability" - a concept similar to the "melodrama of death" or what Craig Haney terms the myth of "demonic agency."144

Mitigation ultimately is about empathy, human kinship, and the diverse frailties of humankind. The former director of the British human rights group Liberty, Shami Chakrabarti, distilled human rights to three core principles: dignity, equality, and

\footnotetext{
${ }^{134} I d$. at $516-18$.

${ }^{135} \mathrm{Id}$. at $518-19$.

${ }^{136} I d$. at $520-22$.

${ }^{137}$ Id. at 522 .

${ }^{138}$ Robert J. Smith, Forgetting Furman, 100 Iowa L. Rev. I I 49 (2015).

${ }^{139} \mathrm{Id}$. at 1151, citing Robert J. Smith et al., The Failure of Mitigation?, 65 Hastings L. J. 1221, 1240 (2014). See also Forgetting Furman at 1187-88 (citing earlier finding that 87 percent of the executed offenders "possessed an intellectual impairment, had not yet reached their twenty-first birthday, suffered from a severe mental illness, or endured marked childhood trauma" and "over half of these offenders fell into multiple mitigation categories").

${ }^{140}$ Smith, Forgetting Furman, supra note 137, at 1153.

${ }^{141} I d$. at 1154 .

${ }^{142} \mathrm{Id}$. at 1173 .

${ }^{143} \mathrm{Id}$. at 1177 and nn. 163, 166-67.

${ }^{144} I d$. at 1189 ; supra at 4-5; Haney, supra note 9.
} 
fairness. ${ }^{145}$ She states that "the greatest of all qualities" in the human rights domain is empathy. ${ }^{146}$ Only the courts can enforce equality and fairness in capital proceedings, but the defense function, through mitigation presented in an effective narrative, can confer dignity on every client and arouse the empathy that enables jurors to reject the punishment of last resort regardless of the horrendous brutality of the crime.

\section{Conclusion}

We end where we began: mitigation matters because it has saved, is currently saving, and will continue to save lives as long as capital punishment exists in this country. As Craig Haney so eloquently wrote two decades ago: "Only if we look honestly at the lives of those who commit capital crimes - and cease to be blinded by the fictionalized, demonized caricatures the media feeds us - can we learn the lessons by which future victims can be spared." ${ }^{147}$ And in matters of investigating, developing, and presenting mitigation, capital defense teams are obligated — both professionally and morally — to invest the time, effort, and resources necessary to construct a narrative for life that defeats the prosecution's dehumanizing melodrama of death. We believe that such a story is present in every capital case and is simply waiting to be found and told. That unshakeable belief lies at the core of this chapter and this book.

\footnotetext{
${ }^{145}$ Shami Chakrabarti, On Liberty 138 (2014).

${ }^{146} \mathrm{Id}$.

${ }^{147}$ Craig Haney, The Social Context of Capital Murder, supra note 9 at 560.
} 